\title{
Multiannual Assessment of the Risk of Surface Water Erosion and Metal Accumulation Indices in the Flysch Stream Using the MARS Model in the Polish Outer Western Carpathians
}

\author{
Wiktor Halecki *, Tomasz Kowalik * and Andrzej Bogdał * \\ Department of Land Reclamation and Environmental Development, Faculty of Environmental Engineering and \\ Land Surveying, University of Agriculture in Krakow, Al. Mickiewicza 24-28, 30-059 Kraków, Poland \\ * Correspondence: wiktor.halecki@urk.edu.pl or wiktor@mailmix.pl (W.H.); rmkowali@cyf-kr.edu.pl (T.K.); \\ a.bogdal@ur.krakow.pl (A.B.)
}

Received: 20 October 2019; Accepted: 12 December 2019; Published: 15 December 2019

\begin{abstract}
The anthropogenic problems in richly sculpted areas (mountain and submontane) are mainly related to agricultural activity, which shapes the quality of surface waters. This paper presents an analysis of the results of the hydrochemical tests carried out in the years 2007-2018 at check-control spots. The heavy metal pollution index $(\mathrm{HPI}<100)$ indicated a low risk for aquatic organisms. The statistical calculations obtained by means of multivariate adaptive regression splines (MARS) designated that the hazard quotient (HQ) index can be combined with the electrical conductivity (EC) and total dissolved substances (TDS) parameters used in the assessment of water erosion. The HQ index showed that the concentration of individual heavy metals is lower than their value in the 0.5 percentile of the value. In subsequent studies, it should be assessed whether the size of arable land has an impact on the increased concentration of heavy metals in the surface water. We recommend small retention reservoirs as a potential management measure to improve the quality of the surface water at a regional scale. This study has great potential to mitigate the degradation processes related to the insufficient storage capacity, and to promote natural water retention.
\end{abstract}

Keywords: surface water quality; flysch stream; heavy metals; catchment use; soil and water conservation; multivariate analysis

\section{Introduction}

The land use of a catchment area is one of the key factors affecting water quality [1]. Water collected in small reservoirs located in rural areas may be polluted, especially in terms of phosphate or ammonium nitrogen concentrations and salinity indices. The amount and type of substances in surface water varies greatly and depends on the conditions in the catchment area [2]. If these substances occur in excess, they deteriorate the quality and utility value of water, and thus become pollutants whose sources can be divided into natural and anthropogenic [2,3]. The reasons for the first of them are rock aeration, the erosion and leaching of soils, clean precipitation, or the decomposition of dying plant and animal organisms [4].

The reason for our study is the presence, in agricultural areas of forests, of mulch in which humus soils occur, which may cause a greater pollution of water with mineral-organic substances than the extensively used (meadows and arable land) mineral soils [5]. The results are strongly inscribed in water-related policies and European Union legislation aimed at rational management of water resources, including socio-economic and climate change [6]. Anthropogenic pollution, which is generally considered to be more dangerous to the aquatic environment, is linked to all human activities, 
in particular industrial and agricultural production, and the progression of urbanization. A significant share of the degradation of water is from rural areas, being used for agricultural purposes; through the chemicalization of agriculture and accelerated soil erosion; improper use of plant protection products and incorrect storage; and the use of sewage or waste from livestock farming $[7,8]$.

Rural settlements also contribute to water pollution, which are connected with diversified population density and land development, non-agricultural economic activity, run-off of polluted water from properties, and communication areas $[9,10]$. The source of hazards may also be deposited gases and dust emitted to the atmosphere from households, which, in dissolved form, reach the surface of the Earth, along with precipitation [11]. A major problem in Poland is also the poor quality of water resources, which are increasingly subject to anthropogenic influences limiting the availability of good quality water $[12,13]$. Therefore, the objectives of the work were divided, and an attempt was made to evaluate the following research problems: (i) physiographic characterization of the upland flysch catchment dominated by agricultural land; (ii) evaluation of the quality indices using multivariate statistics methods; (iii) assessment of anthropogenic pressures and interactions of various factors on heavy metal concentrations; and (iv) estimation of the degree of risk and intensity of water erosion, and the impact of land use on surface water quality.

This study on the hydrochemical assessment of surface water quality has a cognitive and practical aspect, which is suitable for evaluating and issuing expert opinions on the conditions of the location of small retention reservoirs and systematic water quality testing. Moreover, a detailed description of the natural environmental conditions as well as the condition of use and management of the investigated elementary catchments are presented. Qualitative studies, as shown in this paper, are necessary in order to take measures to protect water retained in water reservoirs from pollution.

\section{Material and Methods}

\subsection{Study Area}

The investigated catchment of the Korzen stream and its tributaries is located in the Ciężkowice Foothills in the eastern part of the Małopolskie Voivodeship, in the southern part of Poland. The catchment is dominated by arable land and plant production. It is under pressure from natural factors, mainly water erosion and leaching of soils, as well as anthropogenic factors, mainly related to agricultural activities and rural settlement, including problems with water and sewage management and traffic loads. The stocking density of livestock during the study period was quite low. The total density of the asphalt and paved roads, as well as agricultural and forest roads, is $8.64 \mathrm{~km} \cdot \mathrm{km}^{-2}$. The study area is situated between $21^{\circ} 3.17^{\prime \prime}$ and $21^{\circ} 12.25^{\prime \prime}$ east longitude, and between $49^{\circ} 50.35^{\prime \prime}$ and $49^{\circ} 58.57^{\prime \prime}$ north latitude. According to the Kondracki division [14], the catchment is located in the province of the Western Carpathians and the subprovince of the Outer Western Carpathians.

\subsection{Geometry and Morphometry of the Study Area}

The catchment area is approximately $10 \mathrm{~km}^{2}$ and lies at an altitude of $231.3-396.8 \mathrm{~m}$ above sea level (Figure 1) - the weighted average height is $295.3 \mathrm{~m}$ above sea level. The catchment of the Korzeń stream has a highly concentrated area, as evidenced by the value of the calculated Gravelius index $(\mathrm{K})-1.34$. It is also characterized by a shape similar to a square (form index: $C F=0.45$ ) and circle (circularity index: $\mathrm{CK}=0.55$ ). Hydrological calculations show that each $\mathrm{km}^{2}$ of the catchment area in the Outer Western Carpathians has a significant outflow of water: SSQ $=0.008 \mathrm{~m}^{3} \cdot \mathrm{s}^{-1} \cdot \mathrm{km}^{-2}$, $\mathrm{Q}_{50 \%}=0.0631 \mathrm{~m}^{3} \cdot \mathrm{s}^{-1} \cdot \mathrm{km}^{-2}$, and $\mathrm{Q}_{1 \%}=3.109 \mathrm{~m}^{3} \cdot \mathrm{s}^{-1} \cdot \mathrm{km}^{-2}$. Other important physiographic parameters of the catchment are presented in Table 1 . This indicates the advisability of building small retention reservoirs in such catchments, which can reduce the risk of flooding and reduce the effects of droughts by storing water. 


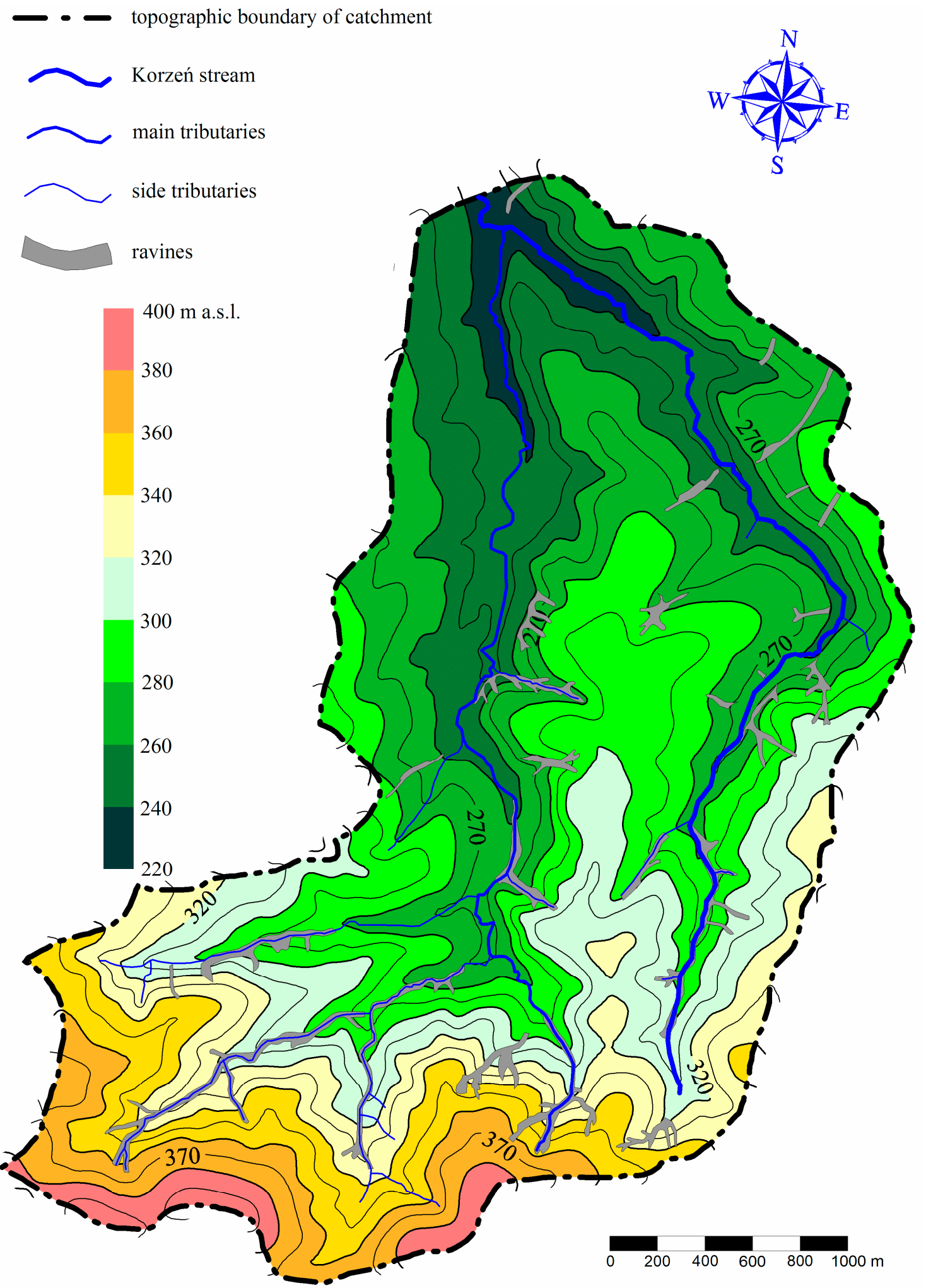

Figure 1. Hypsometric map of flysh stream in catchment area. 
Table 1. The basic physiographic parameters of the catchment.

\begin{tabular}{ccc}
\hline Parameter & Unit & Value \\
\hline Stream length $\left(\mathrm{L}_{\mathrm{G}}\right)$ & $\mathrm{km}$ & 5.11 \\
Direct tributaries length $\left(\mathrm{L}_{\mathrm{D}}\right)$ & & 5.67 \\
Lower-order tributaries length $\left(\mathrm{L}_{\mathrm{D}}^{\prime}\right)$ & & 6.96 \\
Total length $\left(\mathrm{L}_{\mathrm{Tot}}\right)$ & & 17.71 \\
\hline Average width of catchment $\left(\mathrm{B}_{\mathrm{z}}\right)$ & $\mathrm{km}$ & 2.09 \\
Circumference of catchment $\left(\mathrm{O}_{\mathrm{z}}\right)$ & & 14.80 \\
Average length of catchment $\left(\mathrm{L}_{\mathrm{z}}\right)$ & & 4.62 \\
\hline Area of catchment $(\mathrm{A})$ & $\mathrm{km}^{2}$ & 9.65 \\
Water network density $\left(\mathrm{G}_{\mathrm{S}}\right)$ & $\mathrm{km} \cdot \mathrm{km}^{-2}$ & 1.84 \\
Watercourse slope $\left(\mathrm{J}_{\mathrm{c}}\right)$ & $\%$ & 1.5 \\
\hline Form index $(\mathrm{CF})$ & - & 0.45 \\
Elongation index $(\mathrm{CW})$ & & 0.76 \\
Circularity index $(\mathrm{CK})$ & & 0.55 \\
Gravelius index $(\mathrm{K})$ & & 1.34 \\
\hline Annual average flow $(\mathrm{SSQ})$ & $\mathrm{m}^{3} \cdot \mathrm{s}^{-1} \cdot \mathrm{km}^{-2}$ & 0.008 \\
Minimum average flow $(\mathrm{SNQ})$ & & 0.002 \\
Annual minimum low $(\mathrm{NNQ})$ & & 0.001 \\
Flow $\mathrm{Q}_{50 \%}$ & & 0.631 \\
Flow $\mathrm{Q}_{1 \%}$ & & 3.109 \\
\hline
\end{tabular}

In the Korzen stream catchment, the weighted average land gradient is $11 \%$. Slopes of $5-10 \%$ and $10-18 \%$ dominate, which occur on $33.5 \%$ and $37.5 \%$ of the area, respectively. The slopes above $27 \%$ cover only 7.4 ha $(0.8 \%)$ of the area, the share of slopes between $18 \%$ and $27 \%$ is $11.9 \%$, and the slopes smaller than $5 \%$ occupy $16.3 \%$ of the area (Figure 2). In the Korzen stream catchment area, the majority are areas with northern, north-eastern, and north-western exposures, which together, cover $49.5 \%$ of the area. There is also a significant share of the eastern and western exposure areas, whose share in the catchment area is $17.6 \%$ and $11.4 \%$, respectively. The areas with southern exposures that are the most favorable from an agricultural point of view cover $21.5 \%$ of the area. 


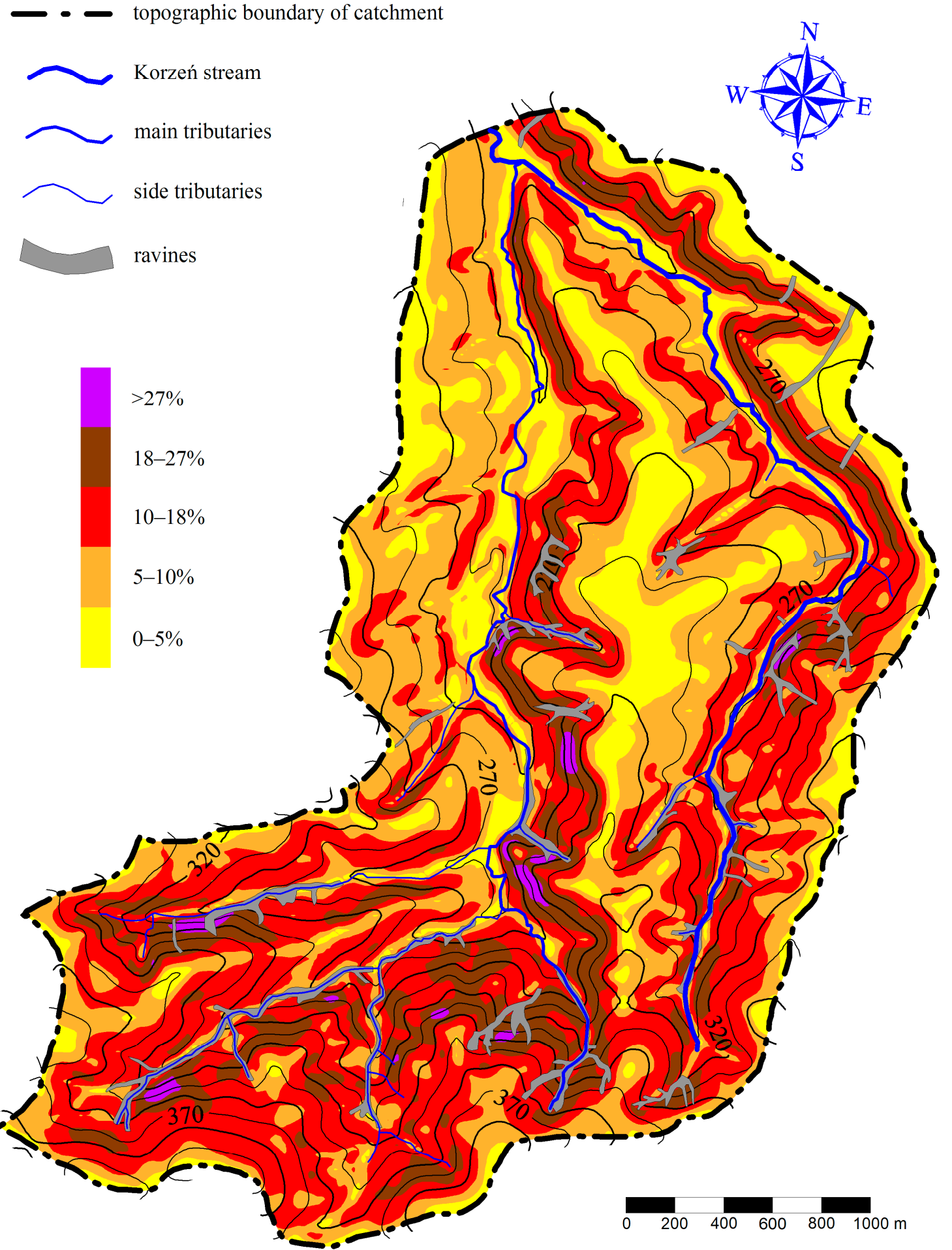

Figure 2. Slope steepness map of flysh stream in catchment area.

In spite of such a diversified relief, which is characteristic for submontane areas, the catchment is well exposed to sunlight, which positively influences the development of agriculture (Figure 3). 


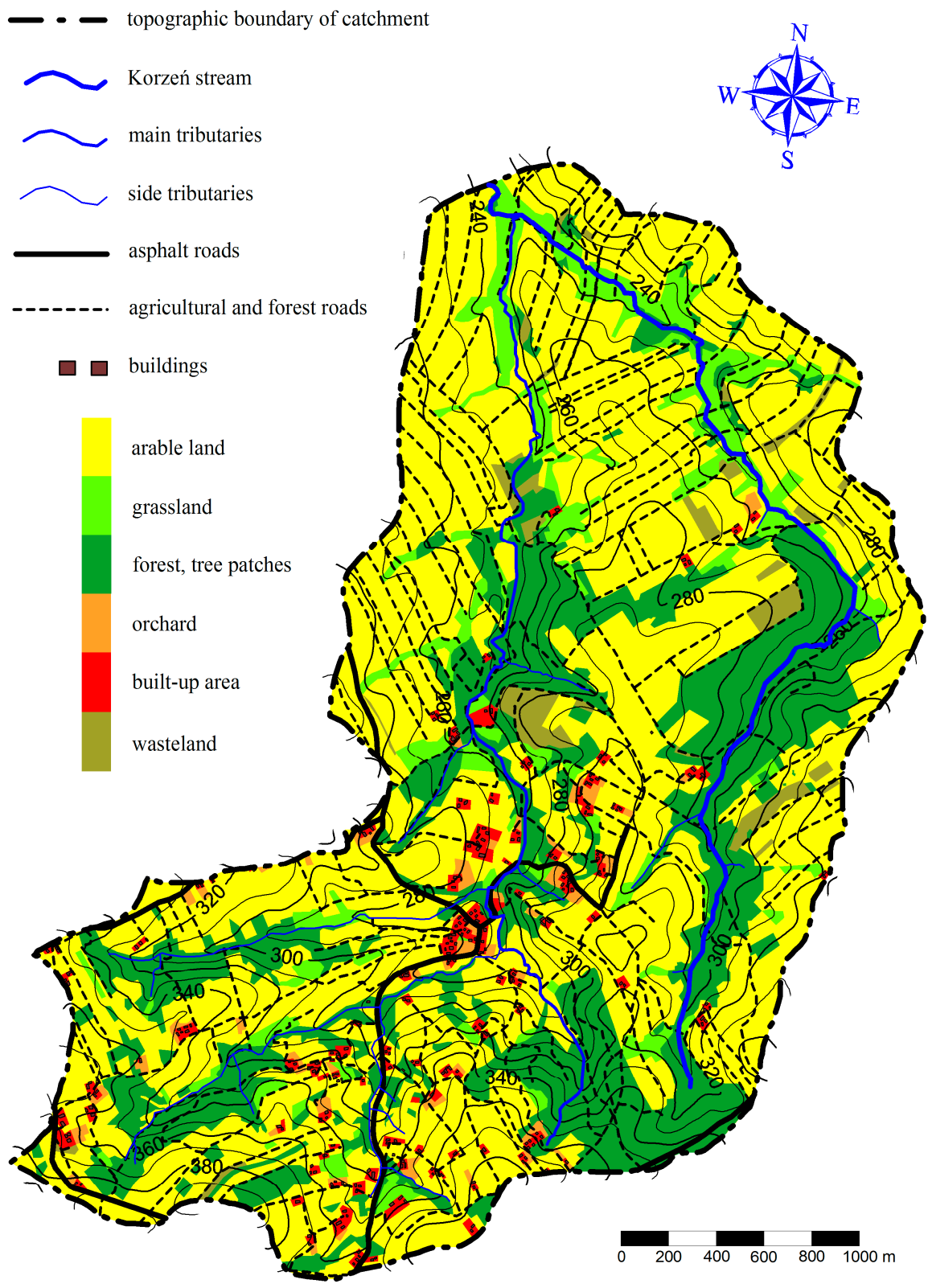

Figure 3. Land-use map of the flysh stream in catchment area.

\subsection{Soils and Land Use}

The northern part of the Ciężkowice Foothills, in which the catchment is located, is situated within the Silesian Nappe, which belongs to the Outer Western Carpathians, also referred to as the flysch Carpathians, because of their geological structure. The Silesian Nappe is the largest unit of the Outer Western Carpathians. Its western part is built of black shale and limestone, coarse sandstone, shale with siderite, siliceous sandstone, and lower Cretaceous shale, as well as a several thousand meters-thick sandstone complex originating from the upper Cretaceous with a small share of shale, referred to as the Godulski Strata and Istebna Strata. The lower Cretaceous formations are strongly corrugated and form several slices at the northern edge of the nappe, while the upper Cretaceous and Palaeogene complexes show a fairly regular fold structure. Along the northern fringe of the Silesian nappe there is a narrow strip of the Subsilesian series. In the section from Cieszyn to Brzesko, this series creates narrow, strongly disturbed scales, overlapping, along with the Silesian series, the deposits of the Miocene. To the southeast of Brzesko and Tarnów, the Silesian Nappe, together with the Subsilesian Nappe, overlap the formations of the younger Palaeogene of the Skole Nappe [14]. 
The catchment of the Korzen stream is characterized by a small typological diversity of soils. The dominant soils are Luvisols, Hamplic Cambisols, and Stagnic Cambisols, which have a 51.6\%, $37.5 \%$, and $9.2 \%$ share, respectively, in the catchment area (Figure 4 ). In $92.1 \%$ of the area, the topsoil genetic layers are made up of silt (Si), and there are also silt loam (SiL), loam (L), and sandy clay loam (SCL). In the largest area, Luvisols are found on the tops and slopes, in all parts of the catchment area of the Korzen stream. These soils are mostly made up of silt (Si) lined with silt loam (SiL). In the southern part of the catchment, mostly under forests, there are Hamplic Cambisols formed from sedimentary rocks with a non-carbonate binder. They are made up of silt (Si) and loam (L), passing at a depth of $25-50 \mathrm{~cm}$ into weekly skeletal sandy loam (SL) deposited on rubble or rocky soils. In the valleys of the Korzeń stream and its tributaries, there are almost exclusively Stagnic Cambisols (Figure 5). In various parts of the catchment (Figure 5), they developed from silt loam (SiL), silt (Si), and loam (L).
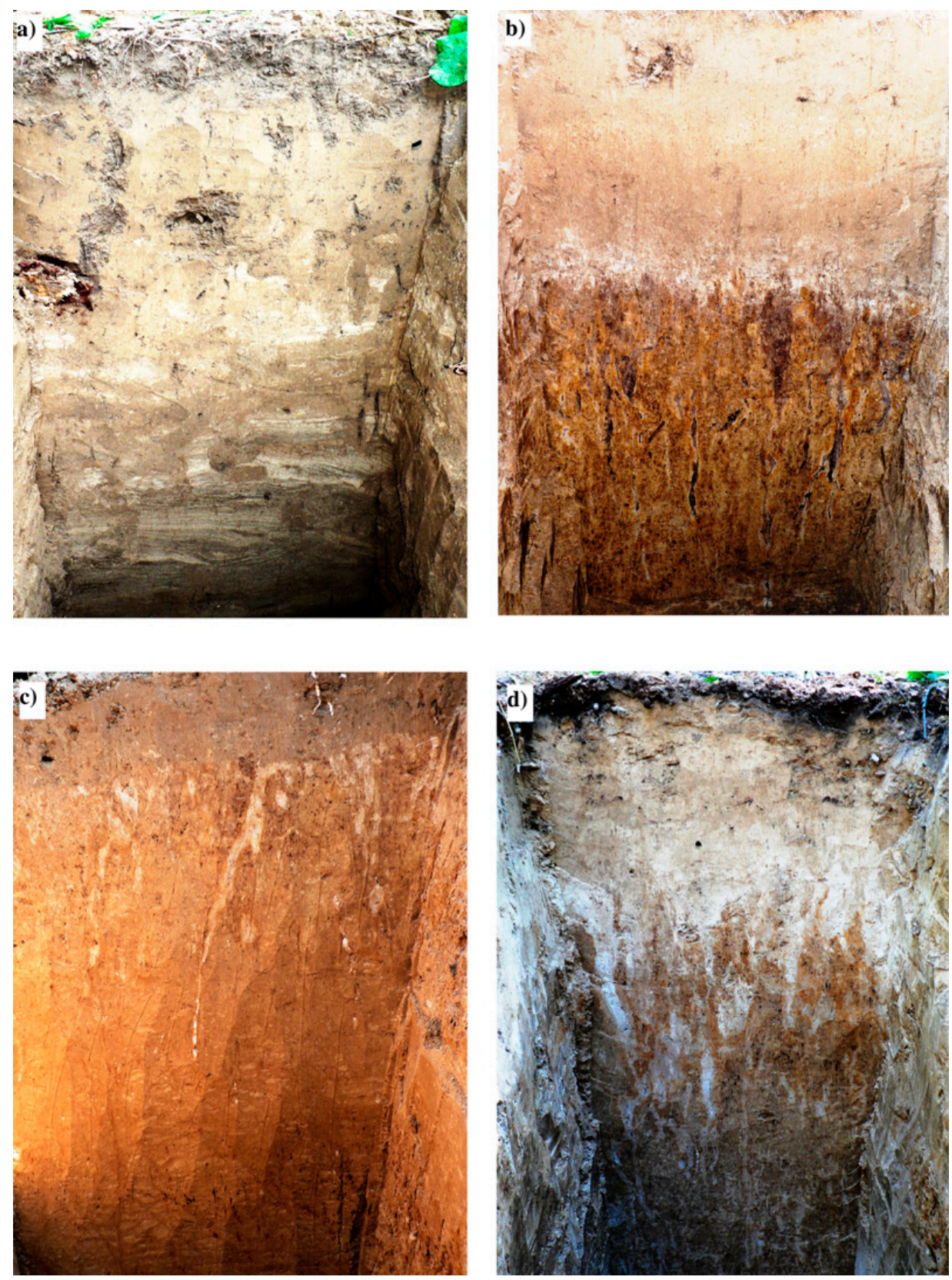

Figure 4. Soil profiles in the studied catchment: (a) Stagnic Cambisol, (b) Stagnic Luvisol, (c) Hamplic Cambisol, and (d) Albic Podzol. 


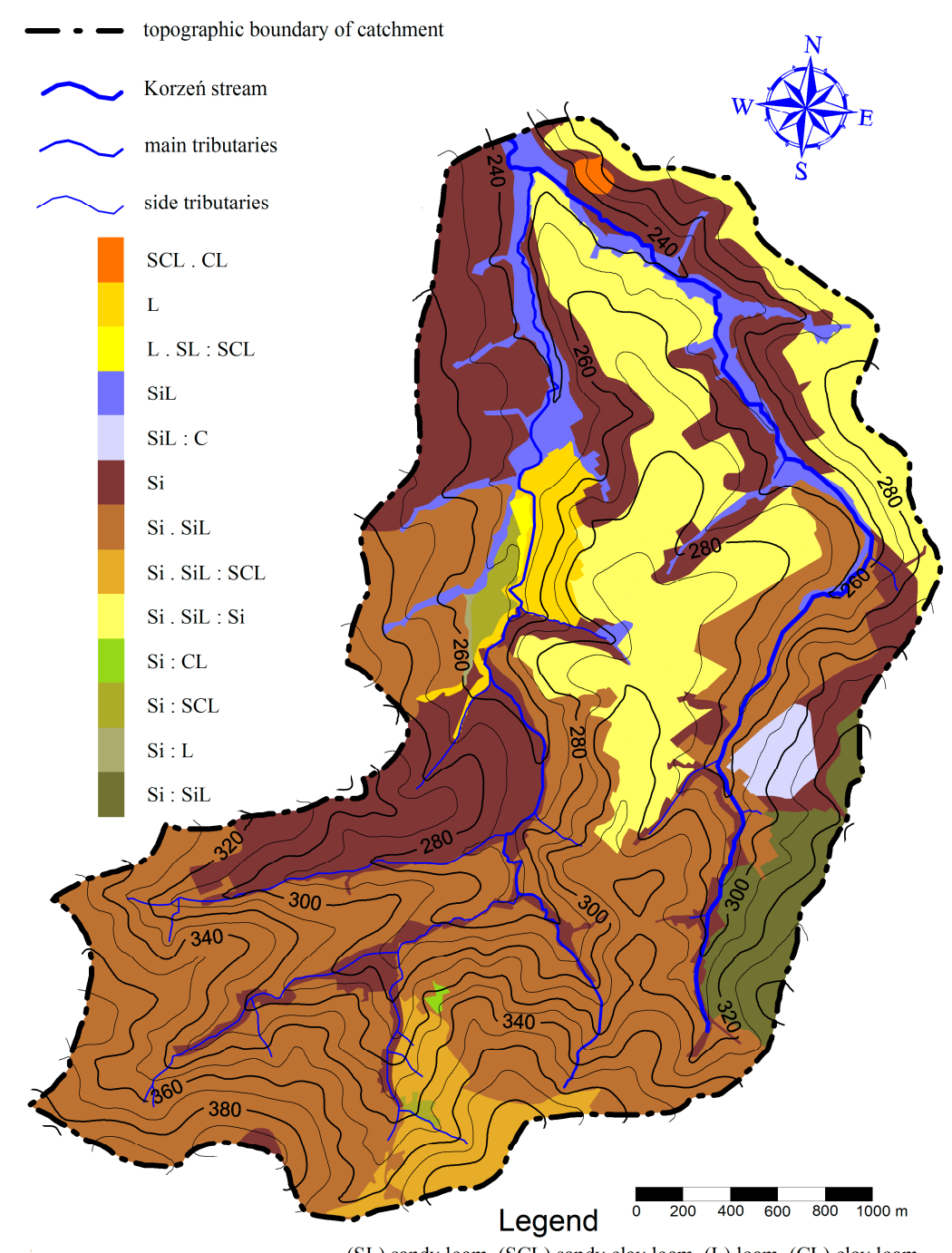

(SL) sandy loam, (SCL) sandy clay loam, (L) loam, (CL) clay loam, $(:)$ the change in granulometric composition occurs at depth 50-100 cm

Figure 5. Soil distribution map of the flysh stream in catchment area.

In the Korzeń stream catchment area, because of the average land gradients and fertile soils, there is $60.7 \%$ of arable land in the area. The arable land is evenly distributed throughout the object and is cultivated mainly with wheat, potatoes, and fodder beet. Grasslands, amounting to $7.7 \%$ of the catchment area, occur almost exclusively in the river valleys. The forestation of the catchment area of the Korzen stream is $25.9 \%$. Larger forest areas, mainly with beech, oak, and fir stand, are located in the central and eastern part of the catchment, while minor wooded and shrubby enclaves occur along all of the watercourses. In addition, there is only a small percentage $(2.1 \%)$ of uncultivated agricultural land in the catchment, and 23.1 ha $(2.4 \%)$ of the areas are with scattered development-they are located in the central and southern part of the catchment, unfortunately very often close to watercourses.

\subsection{Topography and Hydrological Geometry}

Apart from the principal part of the research works related to the determination of physical and chemical properties of water, natural environmental factors as well as the current state of use and management of the analyzed catchment were determined using cartographic materials. The physiographic elaboration of the research catchment was done by the authors.

The following geometrical parameters of the catchment were determined: surface area $(A)$ in $\mathrm{km}^{2}$ calculated by planimetering the area between the topographical boundary of the watershed; average length of the catchment $\left(\mathrm{L}_{\mathrm{z}}\right)$ in $\mathrm{km}$, determined in a straight line from the furthest point on the 
watershed to the closing section; and average width $\left(\mathrm{B}_{\mathrm{z}}\right)$ in $\mathrm{km}$, calculated from the quotient of the catchment surface area and its average length. The following indices were also calculated: form (CF), resulting from the comparison of catchment shape to a square; elongation (CW), expressing the ratio of the diameter of a circle of area equal to the catchment area to the catchment length; circularity (CK), the ratio of the catchment area to the area of a circle of circumference equal to the circumference of the catchment; and watershed development (Gravelius, K), expressing the ratio of circumference of the catchment to the circumference of a circle of area equal to its surface. Moreover, all of the watercourses were digitized, which made it possible to calculate their length $(\mathrm{L})$, density of the river network $\left(\mathrm{G}_{\mathrm{s}}\right)$, and average slope of the main stream Korzen $\left(\mathrm{J}_{\mathrm{c}}\right)$. The following streamflow characteristics were also calculated: annual average flow (SSQ), average minimum flow (SNQ), and minimum annual flow (NNQ), as well as probable outflows, $\mathrm{Q}_{50}$ and $\mathrm{Q}_{1 \%}$.

The shape of the catchment area is shown on a hypsometric map and land slope map. The minimum, maximum, and weighted average absolute height of the catchment were determined. On the basis of the geospatial analysis, the share of individual classes of slopes and the exposure of slopes in the total area of the catchment were determined, and the weighted average slope of the area $(\mathrm{J})$ was calculated. The current use of the catchment is shown on a map prepared with the use of Geographic Information System (GIS) tools on the basis of 1:2000 scale cadastral maps and orthophotomaps, as well as information obtained from the direct inventory of the catchment. As part of the field research, a survey was carried out covering the existing and potential sources of water quality hazard in the catchment. The surveys specified the number and type of households, the way they were supplied with water and the methods of discharging domestic and livestock sewage, the number of inhabitants, the number and density of livestock converted into livestock units (LSU), and the $\mathrm{km}^{2}$ of the catchment area.

The substrate of the catchment was characterized on the basis of digital soil and agricultural maps made available by the Marshal's Office of the Małopolska Voivodeship. On their basis, a map was generated with the help of GIS software, on which the soil types were marked with appropriate colors. The text contains information on the percentage share of the particular types and textures of soil [15] in relation to the total catchment area.

\subsection{Determination of Surface Water Quality Indices}

Hydrochemical tests were carried out at six measurement and check-control spots in the years 2007-2018. Moreover, the concentrations of six heavy metals and the values of two microbiological indices were examined once a quarter. In total, 864 water samples were collected in the research period. During the sampling, for analysis purposes, the $\mathrm{pH}$, using the CP-104 $\mathrm{pH}$ meter (ELMETRON, Zabrze, Poland); specific electrical conductivity (EC), using the CC-102 conductivity meter (ELMETRON, Zabrze, Poland); and the temperature and dissolved oxygen content (DO), using the CO-411 oxygen meter (ELMETRON, Zabrze, Poland) were measured in situ in the waters flowing through the streams under investigation. The following were determined in laboratory: using the gravimetric method, the concentration of the total suspended solids (TSS) and total dissolved substances (TDS), and the concentration of calcium $\left(\mathrm{Ca}^{2+}\right)$, sodium $\left(\mathrm{Na}^{+}\right)$, potassium $\left(\mathrm{K}^{+}\right)$, magnesium $\left(\mathrm{Mg}^{+}\right)$, manganese $\left(\mathrm{Mn}^{2+}\right)$, total iron $\left(\mathrm{Fe}_{\mathrm{Tot}}\right)$, and chromium $\left(\mathrm{Cr}^{6+}\right)$ were calculated; zinc $\left(\mathrm{Zn}^{2+}\right)$, cadmium $\left(\mathrm{Cd}^{2+}\right)$, copper $\left(\mathrm{Cu}^{2+}\right)$, nickel $\left(\mathrm{Ni}^{2+}\right)$, and lead $\left(\mathrm{Pb}^{2+}\right)$ were determined by atomic absorption spectrometry on UNICAM SOLAR 969 spectrometer (unicam Software $\mathrm{GmbH}$, Georgensgmünd, Germany); the concentration of nitrogen in ammoniacal $\left(\mathrm{N}_{-} \mathrm{NH}_{4}{ }^{+}\right)$, nitrite $\left({\mathrm{N}-\mathrm{NO}_{2}}^{-}\right)$, and nitrate $\left(\mathrm{N}-\mathrm{NO}_{3}{ }^{-}\right)$were calculated; the total phosphorus (TP), phosphates $\left(\mathrm{PO}_{4}{ }^{3-}\right)$, and chlorides $\left(\mathrm{Cl}^{-}\right)$were determined by flow colorimetric analysis using the FIAstar 5000 instrument (FOSS, Hillerød, Denmark); the concentration of sulphates $\left(\mathrm{SO}_{4}{ }^{3-}\right)$ was determined by the precipitation-gravimetric method; the five-day biochemical oxygen demand $\left(\mathrm{BOD}_{5}\right)$ was calculated using the Winkler titration method; the chemical oxygen demand (COD-Mn) using boiling titration with $\mathrm{KMnO}_{4}$; and the number of coliforms and fecal coliforms were determined by membrane filtration on lactose media, after incubation at 37 and $44{ }^{\circ} \mathrm{C}$, with a tolerance 
of $0.5^{\circ} \mathrm{C}$. The concentrations of the ammonium $\left(\mathrm{NH}_{4}{ }^{+}\right)$, nitrite $\left(\mathrm{NO}_{2}{ }^{-}\right)$, and nitrate $\left(\mathrm{NO}_{3}{ }^{-}\right)$ions were calculated based on the results of the $\mathrm{N}-\mathrm{NH}_{4}{ }^{+}, \mathrm{N}-\mathrm{NO}_{2}{ }^{-}$, and $\mathrm{N}-\mathrm{NO}_{3}{ }^{-}$determinations. The heavy metals and microbiological indices were determined on a quarterly basis, while the other indices were determined once a month.

\subsection{Erosion Model}

The method proposed by Józefaciuk and Józefaciuk (1999) was implemented using spatial information systems tools (GIS), the basis of which formed a study on the risk of surface water erosion for particular catchment areas was developed. In order to draw up the risk map, the following maps were used: slope maps generated from the numerical terrain model (NMT), soil-agricultural and land use maps, and information about precipitation in the studied region. The minimum area of the region to be analyzed, with an NMT resolution of $20 \mathrm{~m}$ per pixel, was 4 a. The map was filled with information on the percentage share of the areas with a certain degree of erosion risk in the total catchment area. The following computer programs were used to draw up the physiographic features and erosion hazard studies, as well as the mathematical calculations and statistical analyses: MapInfo Professional ${ }^{\circledR} 9.0$ (Pitney Bowes Inc, Stamford, CT, USA), Surfer ${ }^{\circledR} 8.0$ (Golden Software, Golden, CO, USA), CorelDRAW Graphics Suite X4 (Corel, Ottawa, ON, Canada), and ArcGIS 10 (Esri, Redlands, CA, USA).

\subsection{Water Quality Indices}

The degree of water pollution in the investigated streams was assessed using the Burchard and Dubaniewicz formula [16,17]:

$$
\mathrm{W}_{\mathrm{Z}}=\frac{\sum_{1}^{2} \frac{\mathrm{SD}_{\mathrm{t}}}{\mathrm{SW}_{\mathrm{t}}}+\sum_{1}^{\mathrm{n}-2} \frac{\mathrm{SW}_{\mathrm{n}-2}}{\mathrm{SD}_{\mathrm{n}-2}}}{\mathrm{n}}
$$

where $\mathrm{Wz}$ is the impurity coefficient, $\mathrm{SD}_{\mathrm{t}}$ is the permissible dissolved oxygen concentration and fecal coliforms for class I waters (the limit values according to the regulations of 2016 were used for the calculations), $\mathrm{SW}_{\mathrm{t}}$ is the average (over the test period) dissolved oxygen concentration and fecal coliforms, $\mathrm{SW}_{\mathrm{n}-2}$ is the average (over the test period) concentration of the other indices used in the calculations, $\mathrm{SD}_{\mathrm{n}-2}$ is the permissible concentrations of other indices assumed for calculations for the class 1 water quality (limit values according to the regulations [18] were used for the calculations), and $\mathrm{n}$ is the number of indices taken into account.

In accordance with the pragmatics of the method, water is considered to be clean when the impurity coefficient, $\mathrm{W}_{\mathrm{z}}$, is not greater than 0.75 . For the values of the coefficient, $0.76-1.00,1.01-1.50$, $1.51-2.00$, and above 2.00 water were considered to be slightly polluted, clearly polluted, heavily polluted, and waste, respectively.

On the basis of the hydraulic load $\left(\mathrm{O}_{\mathrm{h}}{ }^{\mathrm{zb}}\right)$, taking into account the physical parameters of the water reservoir and the calculated annual load of the total phosphorus, a projection of the trophicity of the planned water body was prepared. The hydraulic load of the reservoir (in $\mathrm{m} \cdot \mathrm{year}^{-1}$ ) was calculated from the following formula [19]:

$$
\mathrm{O}_{\mathrm{h}}^{\mathrm{zb}}=\frac{\mathrm{z}}{\mathrm{t}}
$$

where $\mathrm{z}$ is the average reservoir depth $(\mathrm{m})$ and $\mathrm{t}$ is the average water retention time (years).

It was assumed that the annual phosphorus load of the reservoir corresponds approximately to the phosphorus load transported in the stream at the average annual flow. The criteria according to which an oligotrophic reservoir is a body loaded with phosphorus load of $\mathrm{L}_{\mathrm{P}}{ }^{\text {pow }}$ (in grams $\mathrm{P}$, per $1 \mathrm{~m}^{2}$ area, and in one year), such that $\mathrm{L}_{\mathrm{P}}{ }^{\text {pow }}<0.01\left(\mathrm{O}_{\mathrm{h}}{ }^{\mathrm{zb}}+10\right)$, were used for the assessment. A reservoir is assumed to be eutrophic when $\mathrm{L}_{\mathrm{P}}{ }^{\text {pow }}>0.03\left(\mathrm{O}_{\mathrm{h}}{ }^{\mathrm{zb}}+10\right)$ and mesotrophic when $0.01\left(\mathrm{O}_{\mathrm{h}}{ }^{\mathrm{zb}}+10\right)<$ $\mathrm{L}_{\mathrm{P}}{ }^{\text {pow }}<0.03\left(\mathrm{O}_{\mathrm{h}}{ }^{\mathrm{zb}}+10\right)[18]$.

The objective of the environmental risk assessment (ERA) is to assess the trend and extent of the adverse effects that may occur or do occur as a result of exposure to environmental stressors. In this 
study, an environmental risk assessment of the flysch stream was carried out, assigning a weight of $\mathrm{w}_{\mathrm{i}}=1 \div \mathrm{n}_{\mathrm{i}}$ to each sample, where $\mathrm{n}_{\mathrm{i}}$ is the number of samples in the $i$ th range of the numerical values to which the data are sorted in the statistical analysis. In addition, the hazardous concentration at the fifth centile $\left(\mathrm{HC}_{05}\right)$ has been calculated. The Hazard quotient index $(\mathrm{HQ})$ was obtained by dividing the measured concentration (MEC) at each sampling point by $\mathrm{HC}_{05}$, according to the following formula:

$$
\mathrm{HQ}=\frac{\mathrm{MEC}}{\mathrm{HC}_{05}}
$$

The idea of this method assumes that with values of $\mathrm{HQ} \geq 10$ there is a high ecological risk for aquatic organisms, values between $1.0 \leq \mathrm{HQ}<10$ indicate a moderate risk, values between $0.1 \leq \mathrm{HQ}<1.0$ indicate a low risk, and with $\mathrm{HQ}<0.1$ the risk is reduced [19].

The heavy metal pollution index (HPI) was determined by assigning a rating or weight $\left(\mathrm{W}_{\mathrm{i}}\right)$ for each selected parameter. Weight is any value in the range of 0 to 1 , and its choice reflects the relative individual importance for the quality aspects. It can be defined as inversely proportional to the standard limit value. The assessment of heavy metal pollution in the surface waters of the study area was carried out on the basis of a calculated index [20,21], as follows:

$$
\mathrm{HPI}=\frac{\sum_{\mathrm{i}=1}^{\mathrm{n}} \mathrm{W}_{\mathrm{i}} \cdot \mathrm{Q}_{\mathrm{i}}}{\sum_{\mathrm{i}=1}^{\mathrm{n}} \mathrm{W}_{\mathrm{i}}}
$$

where $Q_{i}$ is the subindex of the next ith parameter, $W_{i}$ is the unit weight assigned to ith parameter, and $\mathrm{n}$ is the number of parameters considered.

The subindex $\left(\mathrm{Q}_{\mathrm{i}}\right)$ is calculated from following equation:

$$
\mathrm{Q}_{\mathrm{i}}=\sum_{\mathrm{i}=1}^{\mathrm{n}} \frac{\left|\mathrm{M}_{\mathrm{i}}-\mathrm{I}_{\mathrm{i}}\right|}{\mathrm{S}_{\mathrm{i}}-\mathrm{I}_{\mathrm{i}}} \cdot 100
$$

where $M_{i}$ is the monitored values of the heavy metal of the ith parameter, $I_{i}$ is the ideal value of the ith parameter, and $S_{i}$ is the maximum allowed or recommended value of the ith parameter.

The unit weight $(\mathrm{Wi})$ of the parameter is determined as follows:

$$
\mathrm{W}_{\mathrm{i}}=\frac{\mathrm{k}}{\mathrm{S}_{\mathrm{i}}}
$$

where $\mathrm{k}$ is a constant of proportionality.

Heavy metal contamination is an issue of serious concern. The heavy metal evaluation index (HEI) gives general information on water quality in relation to the concentrations of heavy metals, and is expressed by the following formula:

$$
\mathrm{HEI}=\sum_{\mathrm{i}=1}^{\mathrm{n}} \frac{\mathrm{M}_{\mathrm{i}}}{\mathrm{S}_{\mathrm{i}}}
$$

The $\mathrm{M}_{\mathrm{i}}$ and $\mathrm{S}_{\mathrm{i}}$ parameters are monitored and the maximum admissible concentration (MAC) of a given parameter, respectively. The higher the concentration of the metal compared to its respective normative value, the worse the water quality.

\subsection{Statistical Analysis and Data Processing}

A Principal Component Analysis (PCA) is a linear combination of the output variables and is used to, among other things, reduce the number of variables. The purpose of the PCA is to generate the main components that are constructed as a linear combination of the output variables. Each of the generated main components should be treated as a weighted combination of the original variables. Those components that explain the variability in a significant way were selected for analysis-the limit value is usually assumed to be $75 \%$. A graphical illustration of the PCA analysis is the projection of 
data, usually in two-dimensional space (PC1 and PC2). The PCA analysis was performed in PQStat (PQStat Software, Poznań, Poland) statistical program in version 1.66.

Based on the obtained results of the hydrochemical tests, an assessment of the degree of differentiation of the concentration of the tested water quality indices was carried out by means of a regression for each variable. Multivariate adaptive regression splines (MARS) were used for the projections. MARS is a non-parametric statistical procedure, particularly useful for a larger number of variables [22]. It does not require assumptions of a functional relationship between the dependent and independent variables. The applied method additionally takes into account the interactions between the explanatory variables. The general form of the weighted sum of the base functions has the following formula [23]:

$$
y=f(X)=\beta_{0}+\sum_{m=1}^{M} \beta_{m} \cdot h_{m}(X)
$$

where $y$ is a function of the predictive variables of $X$ (including interaction), $\beta_{0}$ is the starting ordinate, $\beta_{m}$ is the weighted ordinate (by weights), and $h_{m}(X)$ is the sum of one or more base functions.

The projection was based on the statistical analyses selected in the previous procedure, which reflected the variability of the water quality indices, on the accompanying or disturbing factors, that is the slope or slope exposure, as well as on the soil type. MARS is a method for selecting the most important features (predictors) and reducing (removing) the least important base functions. On the basis of the measurements carried out, a model was created for all of the test points (based on equal cases investigated). Erosion processes in unfavorable habitat conditions may lead to the destruction of the entire soil profile, over time leading to the formation of an erosion landscape. Land at such risk requires comprehensive protective measures, with part of the arable area to be used for anti-erosion equipment. In order to implement the research methodology related to the selection of the significant predictors in the applied model of the explanatory variables, the least squares method was used to estimate the parameters. The generalized cross validation (GCV) was calculated according to the following formula [23]:

$$
\operatorname{GCV}(M)=\frac{1}{n} \frac{\sum_{i=1}^{n}\left[y_{i}-f_{M}\left(x_{1}\right)\right]^{2}}{\left[1-\frac{P(M)}{n}\right]^{2}}
$$

where $y_{i}$ is the ith observed response value; $f_{M}\left(x_{1}\right)$ is the fitted response value obtained for the ith observed predictor vector; $\mathrm{n}$ is the number of cases (observations); $\mathrm{M}$ is the maximum number of base functions selected for the model; and $\mathrm{P}(\mathrm{M})$ represents the effective number of parameters, which is a penalty measure for the complexity.

GCV determines the error in fitting the model to the real data and takes into account both the residual error and the complexity of the model. Therefore, the applied statistical measures allow for identifying significant changes in the research area. Both the hydrochemical and physiographic parameters were compared. The results of the MARS model were elaborated in the statistical program Statistica 12.5 (StatSoft, Tulsa, OK, USA), and the selection of the functions to the model was made using the Gnu Regression, Econometrics and Time-series Library (GRETL) calculation program (General Public License-open source).

The significance of the dynamics of the changes in the values of the water quality indices was assessed using the Permutational multivariate analysis of variance (PERMANOVA) two-factor test. The homogeneity of variance was tested using the Levene test. To assess the differences between the land use forms, an analysis of the inequalities of the variance was carried out with the F-Welch test. The calculations were performed with the use of PAST software version 3.14 (Natural History Museum, University of Oslo, Oslo, Norway). 


\section{Results}

\subsection{Physicochemical Indices}

In the tested watercourses, the water temperature ranged from 0.0 to $24.3^{\circ} \mathrm{C}$ at the individual measurement dates, with the average for the study period at the level of $9.2-12.4{ }^{\circ} \mathrm{C}$. The concentrations of the total suspended solids ranged from 4.87 to $63.99 \mathrm{mg} \cdot \mathrm{dm}^{-3}$. At relatively low water temperatures and low concentrations of nutrients, favorable aerobic conditions occurred in the streams. The minimum concentration of dissolved oxygen in water never decreased below the level of $5 \mathrm{mg} \mathrm{O}_{2} \cdot \mathrm{dm}^{-3}$, which was undoubtedly influenced by the significant slopes in the bottom of the watercourses, and the associated high water flow rates. The average oxygen concentration in the study period ranged from 9.50 to $10.43 \mathrm{mg} \mathrm{O}_{2} \cdot \mathrm{dm}^{-3}$. The mean values of $\mathrm{BZT}_{5}\left(1.50-2.21 \mathrm{mg} \mathrm{O}_{2} \cdot \mathrm{dm}^{-3}\right)$ were relatively low, which indicates a low concentration of organic compounds easily soluble in surface waters. On the other hand, the chemical oxygen demand (COD-Mn) was higher, which also depends on the concentration of the organic substances with a low susceptibility to degradation, with mean values from 6.11 to $8.03 \mathrm{mg} \mathrm{O}_{2} \cdot \mathrm{dm}^{-3}$ (Table 2).

Table 2. Average values of the physicochemical parameters. TSS—-total suspended solids; DO—dissolved oxygen content; $\mathrm{BOD}_{5}$ - five-day biochemical oxygen demand; COD-Mn—chemical oxygen demand.

\begin{tabular}{|c|c|c|c|c|c|c|c|}
\hline \multirow{2}{*}{ Parameter } & \multirow{2}{*}{ Unit } & \multicolumn{6}{|c|}{ Sampling Sites } \\
\hline & & 1 & 2 & 3 & 4 & 5 & 6 \\
\hline TSS & $\mathrm{mg} \cdot \mathrm{dm}^{-3}$ & 6.50 & 4.87 & 8.47 & 55.79 & 5.77 & 63.99 \\
\hline DO & & 10.10 & 9.50 & 10.10 & 10.13 & 10.27 & 10.43 \\
\hline $\mathrm{BOD}_{5}$ & & 1.50 & 2.12 & 1.92 & 2.11 & 2.21 & 1.95 \\
\hline COD-Mn & & 6.11 & 7.85 & 8.03 & 7.42 & 7.53 & 6.72 \\
\hline $\mathrm{PO}_{4}^{3-}$ & & 0.07 & 0.05 & 0.04 & 0.08 & 0.03 & 0.08 \\
\hline $\mathrm{P}_{\mathrm{Tot}}$ & & 0.03 & 0.01 & 0.01 & 0.03 & 0.01 & 0.03 \\
\hline $\mathrm{N}-\mathrm{NH}_{4}$ & & 0.08 & 0.04 & 0.07 & 0.04 & 0.04 & 0.05 \\
\hline $\mathrm{NH}_{4}^{+}$ & & 0.09 & 0.06 & 0.09 & 0.05 & 0.05 & 0.06 \\
\hline $\mathrm{N}-\mathrm{NO}_{2}{ }^{-}$ & & 0.02 & 0.01 & 0.01 & 0.01 & 0.01 & 0.02 \\
\hline $\mathrm{NO}_{2}{ }^{-}$ & & 0.05 & 0.04 & 0.04 & 0.05 & 0.04 & 0.05 \\
\hline $\mathrm{N}-\mathrm{NO}_{3}{ }^{-}$ & & 0.76 & 0.56 & 0.63 & 0.98 & 0.71 & 1.31 \\
\hline $\mathrm{NO}_{3}^{-}$ & & 3.36 & 2.48 & 2.81 & 4.33 & 3.14 & 5.79 \\
\hline TDS & & 239 & 182 & 181 & 183 & 181 & 201 \\
\hline $\mathrm{SO}_{4}{ }^{2-}$ & & 40.96 & 30.64 & 29.41 & 30.34 & 31.47 & 40.17 \\
\hline $\mathrm{Cl}^{-}$ & & 11.38 & 10.27 & 10.72 & 9.74 & 10.70 & 14.15 \\
\hline $\mathrm{Ca}^{2+}$ & & 65.30 & 58.58 & 59.84 & 63.7 & 61.15 & 72.93 \\
\hline $\mathrm{Mg}^{2+}$ & & 9.93 & 8.46 & 9.05 & 10.91 & 8.75 & 9.16 \\
\hline $\mathrm{Na}^{+}$ & & 10.66 & 8.75 & 8.94 & 9.60 & 8.99 & 10.94 \\
\hline $\mathrm{K}^{+}$ & & 2.64 & 2.63 & 2.52 & 2.09 & 2.66 & 3.05 \\
\hline $\mathrm{Mn}^{2+}$ & & 0.32 & 0.26 & 0.27 & 0.42 & 0.26 & 0.18 \\
\hline $\mathrm{Fe}_{\mathrm{Tot}}$ & & 0.66 & 0.30 & 0.38 & 0.96 & 0.38 & 0.65 \\
\hline Temperature & ${ }^{\circ} \mathrm{C}$ & 10.0 & 12.4 & 11.9 & 9.3 & 12.2 & 9.2 \\
\hline $\mathrm{pH}$ & - & 7.94 & 7.98 & 7.99 & 7.92 & 8.01 & 7.98 \\
\hline EC & $\mu S \cdot \mathrm{cm}^{-1}$ & 386 & 352 & 354 & 378 & 362 & 415 \\
\hline
\end{tabular}

The highest average concentration of the total phosphorus was $0.03 \mathrm{mg} \mathrm{dm}^{-3}$, and the highest average concentration of $\mathrm{PO}_{4}{ }^{3-}$ was $0.08 \mathrm{mg} \mathrm{dm}^{-3}$. The highest average concentration of the ammoniacal nitrogen was recorded at the level of $0.08 \mathrm{mg} \mathrm{dm}^{-3}$. The average concentrations of the total iron ranged from 0.30 to $0.96 \mathrm{mg} \mathrm{dm}^{-3}$, and the manganese concentration was almost two times lower $\left(0.18-0.42 \mathrm{mg} \mathrm{dm}^{-3}\right)$. The highest average concentrations of nitrite nitrogen and nitrate nitrogen ( 0.05 and $1.31 \mathrm{mg} \mathrm{dm}^{-3}$, respectively) were at the level most frequently found in lightly polluted flowing waters (Table 2). The majority of metals showed a very large range of changes in their concentrations in 
the surface waters studied. The low level of anthropopression in the catchments was confirmed by the level of salinity of the tested waters with concentrations of sulphates and calcium, and several times lower concentrations of chlorides and magnesium. Thus, the waters of the streams were generally characterized by an average concentration of dissolved substances and moderate specific electrical conductivity. Detailed results of other indices are presented in Table 2.

\subsection{Relation Between Land-Use and Physicochemical Indices}

The study exposed the visual interpretation of the soil erosion and the risk of soil erosion. The results indicated a strong need to focus on both soil and water erosion. According to the Burchard and Dubaniewicz formula [16], the water of the Korzeń stream was considered to be heavily polluted on the basis of the impurity coefficient $(\mathrm{Wz}=1.85)$, calculated on the basis of 10 physicochemical and microbiological indices. The subsequent calculations show that a small retention reservoir with a hydraulic load of $15.8 \mathrm{~m}_{\text {year }}{ }^{-1}$, with currently transported phosphorus loads of $0.27 \mathrm{gP} \cdot \mathrm{m}^{-2} \cdot \mathrm{year}^{-1}$, and an average time of water exchange of 70 days of the year, will be mesotrophic.

The paper compares the values of the individual parameters. One of the largest factorial loads from the PCA analysis was selected (Figure 6). Additionally, the metal accumulation indices were evaluated in order to show the relation between the physicochemical parameters and the degradation of the catchment. According to our study, the most positive factors were the COD-Mn, $\mathrm{BOD}_{5}$, and $\mathrm{Fe}_{\text {Tot }}$ values. We also observed a relationship between TDS and TSS (Table 3 and Figure 6).

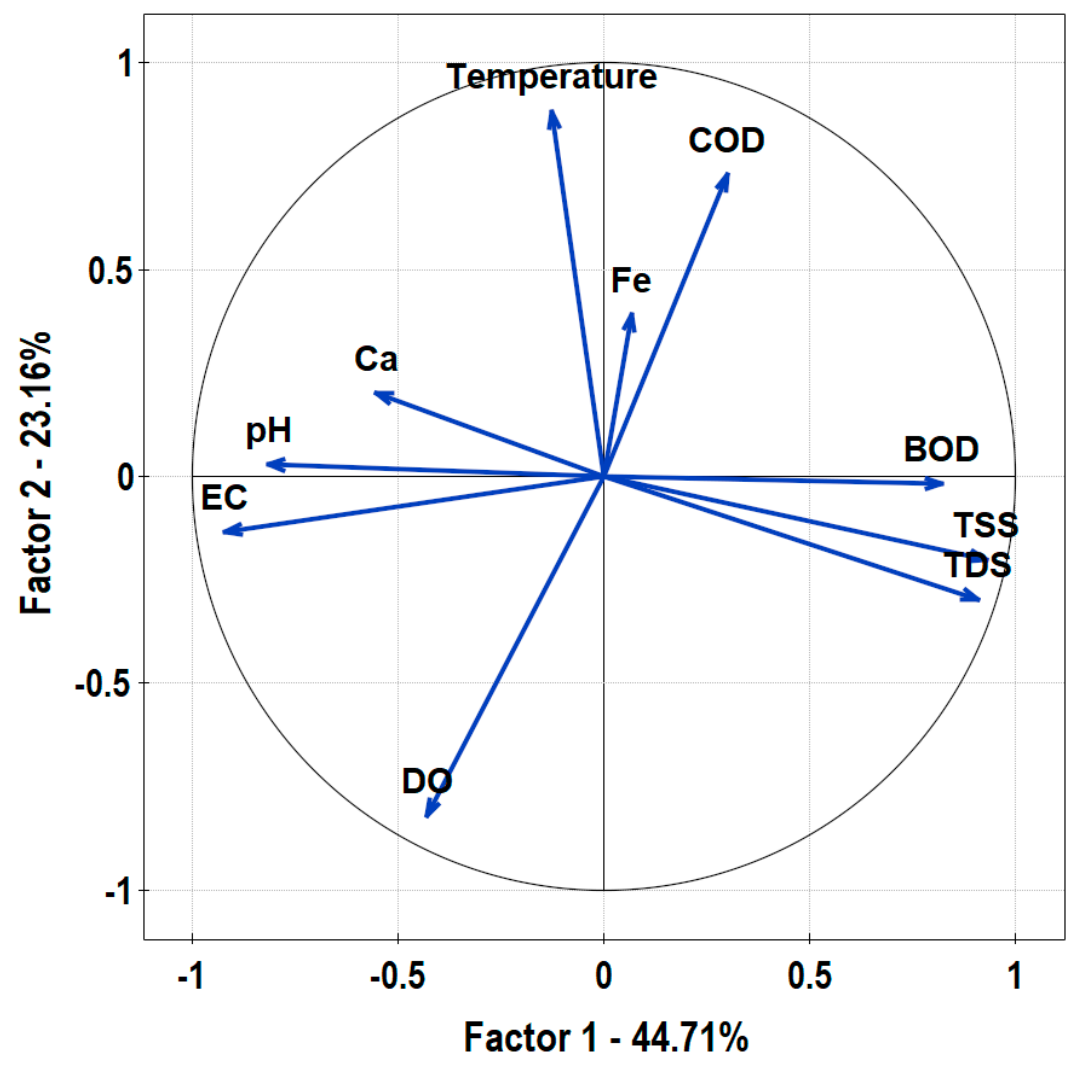

Figure 6. Principal Component Analysis (PCA) plot showing the relationship between the main physiochemical parameters in the research area. The PCA performed a multivariate analysis of the primary matrix to elucidate the correlation structure and to reduce the number of input variables for further analyses. TSS corresponded with TDS, however, DO was negatively related with other variables (Keiser-Mayer-Olkin coefficient $(\mathrm{KMO})=0.62$; Bartletta test $p<0.001 ; \mathrm{df}=45)$. 
Table 3. Loading factors of the greatest importance for the physicochemical parameters.

\begin{tabular}{ccccccc}
\hline \multirow{2}{*}{ Variable } & \multicolumn{7}{c}{ Loading Factors } \\
\cline { 2 - 7 } & Factor 1 & Factor 2 & Factor 3 & Factor 4 & Factor 5 & Factor 6 \\
\hline Temperature & $\mathbf{- 0 . 1 3}$ & $\mathbf{0 . 8 8}$ & -0.36 & -0.05 & 0.14 & -0.13 \\
$\mathrm{Fe}_{\text {Tot }}$ & 0.07 & 0.39 & $\mathbf{0 . 7 3}$ & -0.52 & -0.10 & -0.17 \\
pH & $\mathbf{- 0 . 8 1}$ & 0.03 & -0.16 & -0.02 & 0.26 & -0.45 \\
$\mathrm{DO}$ & -0.43 & $\mathbf{- 0 . 8 2}$ & 0.26 & 0.15 & -0.14 & -0.13 \\
$\mathrm{EC}$ & $\mathbf{- 0 . 9 2}$ & -0.13 & 0.01 & 0.14 & -0.16 & -0.19 \\
$\mathrm{BOD} 5$ & $\mathbf{0 . 8 2}$ & -0.02 & 0.23 & 0.32 & 0.04 & -0.30 \\
$\mathrm{COD}-\mathrm{Mn}$ & 0.30 & $\mathbf{0 . 7 3}$ & 0.19 & 0.46 & -0.31 & -0.06 \\
$\mathrm{TSS}$ & $\mathbf{0 . 9 3}$ & -0.20 & -0.06 & -0.06 & 0.20 & -0.11 \\
$\mathrm{TDS}$ & $\mathbf{0 . 9 1}$ & -0.30 & 0.02 & 0.02 & 0.19 & -0.12 \\
$\mathrm{Ca}^{2+}$ & -0.55 & 0.20 & 0.54 & 0.28 & 0.48 & 0.22 \\
\hline
\end{tabular}

The statistically significant values are marked in bold, for $\alpha=0.05$.

\subsection{Evaluation of Erosive Intensity}

In the catchment, the urgent protection of the land against erosion is required. The land use structure was assessed using the erosion hazard classification, requiring comprehensive anti-erosion measures [24]. In the Korzeń stream catchment area, there was a relatively large area of land threatened by moderate erosion $-25.6 \%$ of the area. In total, more than $32 \%$ of the area was at risk of medium, strong, and very strong water erosion (degrees 3,4 , or 5 ). The smallest slopes of the area, with a water erosion of degree 1 , covering $13.9 \%$ of the area of the examined catchment, caused only small arable, topsoil run-off, and the losses resulting from this could be easily removed by tillage means. Moreover, $0.5 \%$ of the catchment area was at risk of very strong erosion, devastating the entire soil profile along with the bed, and in extreme cases, leading to permanent land degradation (Figure 7).

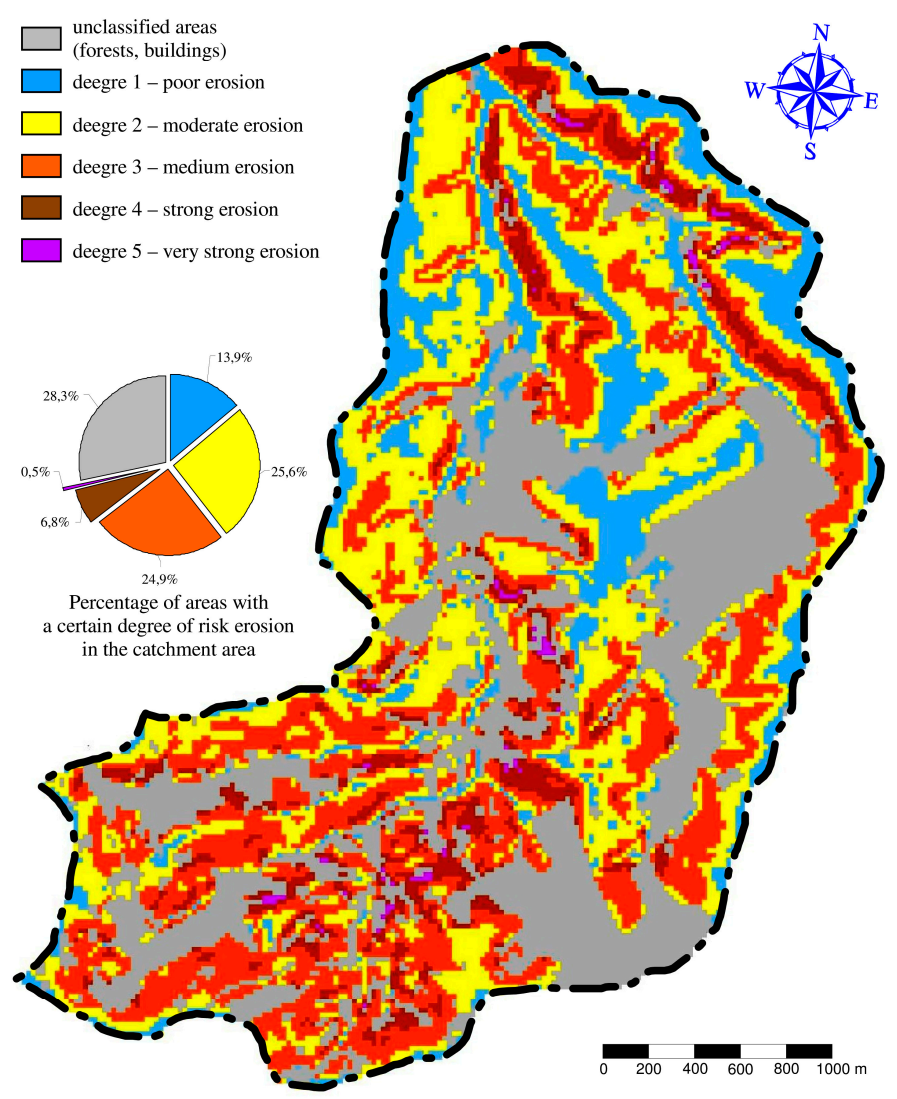

Figure 7. Water erosion classes in investigated area. 


\subsection{Evaluation of Metal Accumulation Factors}

On the basis of the results obtained, for each type of use, the degree of differentiation in the concentration of heavy metals was evaluated. The average concentrations of $\mathrm{Cd}^{2+}\left(0.0001 \mathrm{mg} \cdot \mathrm{dm}^{-3}\right)$, $\mathrm{Pb}^{2+}\left(0.002 \mathrm{mg} \cdot \mathrm{dm}^{-3}\right), \mathrm{Zn}^{2+}\left(0.009 \mathrm{mg} \cdot \mathrm{dm}^{-3}\right), \mathrm{Cu}^{2+}\left(0.003 \mathrm{mg} \cdot \mathrm{dm}^{-3}\right), \mathrm{Ni}^{2+}\left(0.003 \mathrm{mg} \cdot \mathrm{dm}^{-3}\right), \mathrm{Cr}^{6+}$ $\left(0.005 \mathrm{mg} \cdot \mathrm{dm}^{-3}\right), \mathrm{Mn}^{2+}\left(0.29 \mathrm{mg} \cdot \mathrm{dm}^{-3}\right)$, and $\mathrm{Fe}_{\mathrm{Tot}}\left(0.56 \mathrm{mg} \cdot \mathrm{dm}^{-3}\right)$ were included for calculating the metal accumulation indices. The average HPI for arable land was 19, for meadows 13 , and for forests 12. The average HEI values for the individual uses were at a very similar level of about 0.60 (Table 4). The MARS model has shown that the HQ index is suitable for assessing water quality on the basis of the physicochemical parameters; therefore, it was included in the analysis of test results, where hazard classes showing the effect of water erosion on surface water quality have been set. The relationships with the most fitted function are shown in Figures 8 and 9. An HQ value of 4.56 for forest areas indicates a moderate risk of pollution. The values calculated for arable land and meadows ( 0.53 and 0.45 , respectively) indicate a low level of pollution risk (Table 4).

Table 4. Indicators of metal accumulation in particular types of land use. HPI-heavy metal pollution index; HEI-heavy metal evaluation index; HQ-Hazard quotient index.

\begin{tabular}{cccc}
\hline \multirow{2}{*}{ Land-Use Type } & \multicolumn{3}{c}{ Indicators of Metal Accumulation } \\
\cline { 2 - 4 } & HPI & HEI & HQ \\
\hline Arable land & 19 & 2.56 & 0.53 \\
Meadow & 13 & 2.67 & 0.45 \\
Forest & 12 & 2.56 & 4.56 \\
\hline
\end{tabular}

\section{Discussion}

Our technique might be suitable to understand the risk assessment and ecological consequences, such as pollution, associated with anthropogenic implication. Statistical analyses and water quality indices can effectively be imposed for land-related policies We confirmed the methodological strengths benefitting from natural water retention measures. This article raises awareness about decision makers to formulate appropriate policies for farmers. This study exposed that visual land use mapping may be applied to show the value of innovative design features, and favorable natural conditions in the context of water storage structures.

\subsection{Anthropogenic Threats to Water Quality}

Hydrochemical research carried out in small, uncontrolled, non-urbanized catchments usually indicates broadly understood agricultural activity and settlements as the main causes of surface water pollution in rural areas [25-28]. In rural areas, the quality of surface water running off from areas of agricultural, or agricultural and settlement use is the result of many factors. Their influence on the formation of the physicochemical composition and utility values of these waters is different and varies in time [29,30]. In small catchments, the anthropogenic effect on surface water quality is almost always intertwined with the effect of natural factors, that is, the dissolution of rocks, erosion, and leaching of uncultivated soils; inflow of humus substances; decomposition of organic matter; and, to some extent, precipitation [31].

An important cause of surface water degradation is the intensive inflow of nutrients (nitrogen, phosphorus, and their compounds). In our work, the maximum load on the surface of the reservoir with a capacity of about 0.5 million $\mathrm{m}^{3}$ and an average depth of $3.0 \mathrm{~m}$ with phosphorus was $0.27 \mathrm{gP} \cdot \mathrm{m}^{-2} \cdot$ year $^{-1}$. With this type of load inflow $\mathrm{P}_{\text {Tot }}$, the reservoir will be of a mesotrophic nature. Nutrients often originate from point sources that are connected with the absence or inadequate management of water and wastewater [32]. The migration of phosphorus between the source points and the inflow into the river bed was clearly related to the use of the catchment area [33]. The problem may be solved by modernizing the existing and constructing and increasing the number of new sewage 
treatment plants in rural areas [32]. Already today in Poland, as estimated by the Helsinki Commission, more than $50 \%$ of the biogenic pollution found in surface waters has its origins in the area sources of pollution [34].

In rural areas, anthropogenic pressure on the surface water quality is related to plant and animal production. In addition, there is pollution from settlement areas resulting from the discharge of untreated or insufficiently treated wastewater, and from rainwater flushing various substances from properties, traffic areas, and waste dumps [7]. On the basis of the calculated impurity coefficient with the Burchard and Dubaniewicz formula $(\mathrm{Wz}=1.85)$, it can be concluded that the surface waters running off the catchment were heavily polluted.

\subsection{Land Use, Prognostic-Regressive Method, and Systematic Studies of Surface Water Quality}

A serious threat to water quality is the leaching of nutrients from soils, and their different uptake by plants during the vegetation period, and from the non-vegetable soil of cultivated fields in the non-vegetation period. The supply source exhibits a supply of fresh material from the surrounding areas. The main ions indicate water alkalinity [35]. The multivariate adaptive regression splines method showed relations between EC $\left(R^{2}=0.72\right)$ and TDS $\left(R^{2}=0.71\right)$ and the HQ index. A graph of the basic spline function of the two first-degree variables versus variable $x$, and the first degree versus variable $y$ is shown in Figures 8 and 9. The use of hydrochemical variables for projecting greatly expands the computational capabilities. Many factors would be omitted if the variables to which the measured numerical values can be assigned had to be used exclusively. Knowledge of the regression function alone does not make it possible to assess the discrepancy between the predictions and the measurement values. The MARS modelling showed relations for the HQ metal accumulation index. As the HQ increased, the values for EC (Figure 8) and TDS (Figure 9) in the waters passing through the field complex increased, which means that both indices are suitable for pollution assessment. They can play a role as indices for the quality of water flowing out of a typical agricultural catchment.

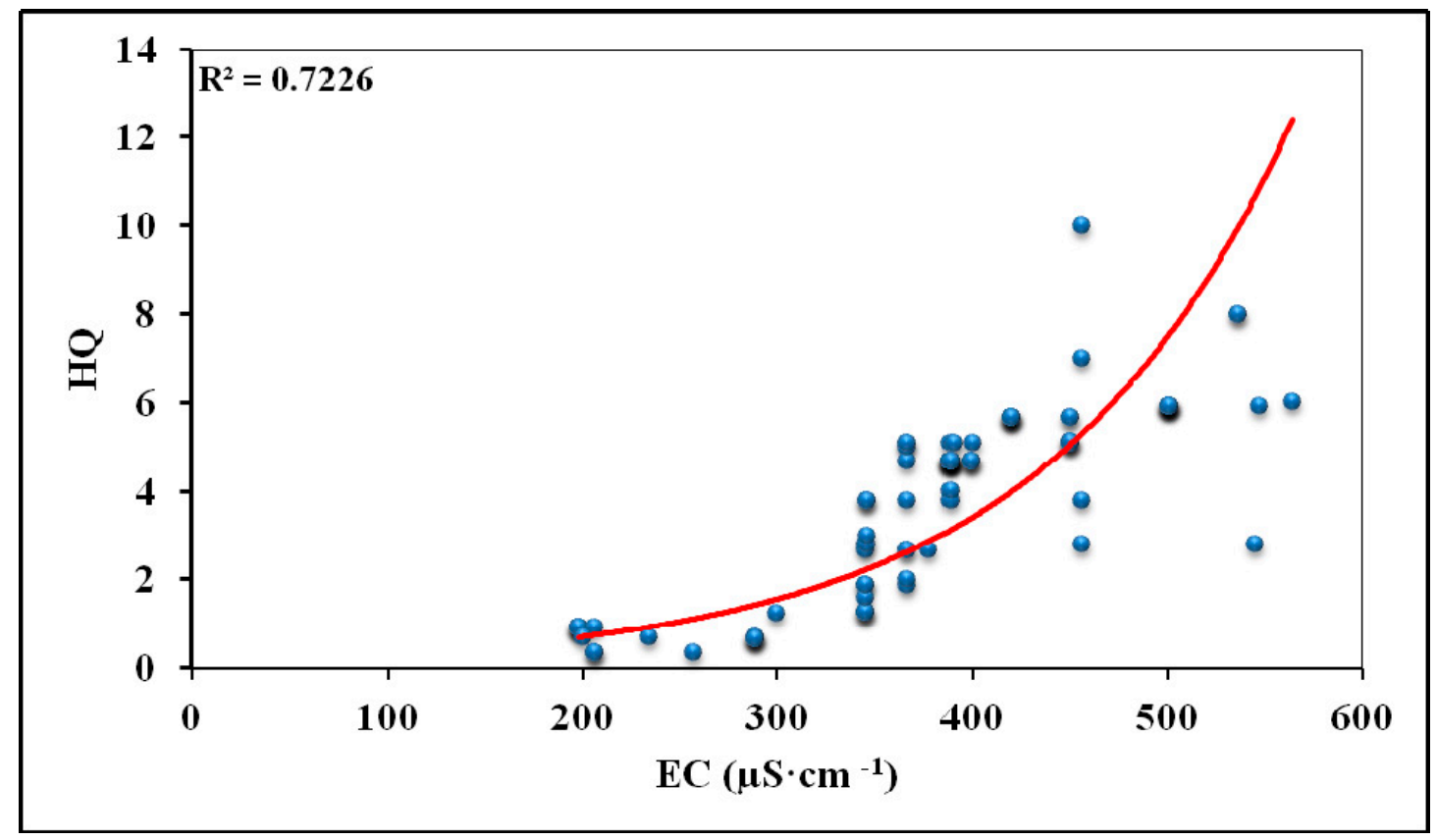

Figure 8. Relationship between hazard quotient (HQ) index and electrical conductivity (EC) using multivariate adaptive regression splines (MARS) model. 


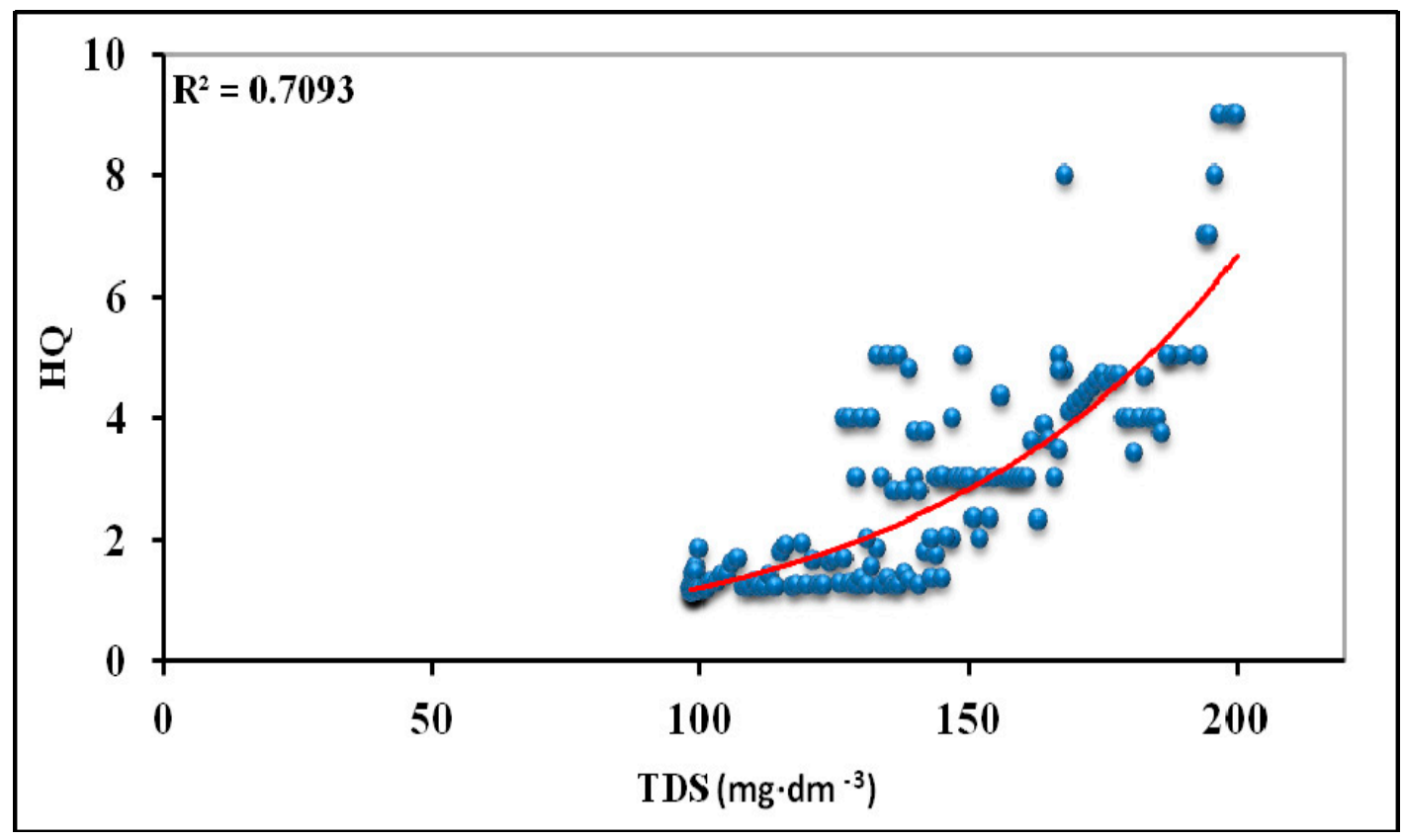

Figure 9. Relationship between HQ and total dissolved solids (TDS) using the MARS model.

The presence of heavy metals alone in surface water indicates pollution [36]. The HPI (heavy metal pollution index) is suitable for a comparison of the places exposed to heavy metal activity [10]. The obtained physicochemical indices may be proposed for the selection of the factors useful in hydrochemical evaluation [37], or the modelling of relations between catchment features and water quality [38]. The dependence of the concentration of the selected indices of water quality in small water reservoirs may be confirmed by the use of the catchment. In catchments with a predominance in the structure of forest and grassland use, and catchments with a predominance of forest and agricultural land, a similar distribution of nutrient concentrations is the result of similar morphometric and physiographic parameters and catchment use [29].

The highest risk of surface water erosion occurred on arable land. The weak and moderate erosion covered $26.5 \%$ of the area. Severe potential erosion destroyed the topsoil and created grooves, which cannot be compensated by standard agrotechnical procedures (Figure 7). This is particularly important in the context of protecting small water retention reservoirs against silting. The obtained results of the study allow us to conclude that the use of the catchment area is one of the key factors shaping water quality.

Field studies from the same measurement and check-control spots indicate that anthropogenic transformations of the agricultural-forest catchment are of great importance. The reason for such a tendency should be sought in the fact that the presence of urbanized areas carry a serious risk not so much of the area, but of the point pollution of surface waters. This indicates a very urgent need to protect their area from the destructive effects of surface water [39], and the trend of agricultural use of the catchment cannot be ruled out.

\subsection{Protection of Soils and Water in Upland and Mountain Catchment Areas}

The spatial relationships between land use exhibit diversity within the entire catchment and the related sources of pollution [40-47]. The physicochemical parameters of water quality can be used to illustrate the general trends related to the hydrogeochemical environment in the catchment $[48,49]$, while water quality indices are used as hydrochemical standards for determining the pollution sources [50,51].

The outflow of suspended sediment solids from settlement and agricultural areas is connected with the physiographic parameters of the catchment, and increased concentrations of nitrate nitrogen and 
total phosphorus in surface waters [29]. The reason for this is the unregulated water and wastewater management in the catchment area. Spatial relationships with factors such as the topography, slope, and exposure of the catchment have an impact on its use and water quality in the catchment [52]. Our research indicates that the reason for this trend is agricultural activity, which intensifies the runoff of TSS. However, water quality assessment, covering also calcium ions, should be carried out. The multidimensional analysis showed that the components that significantly explained the variability of the physicochemical parameters with the largest anthropogenic transformations of the catchment had $67.9 \%$ of the explanatory variance, and could show an influence on the water quality. Graphically, the PCA results are illustrated in the data projection in the two-dimensional space shown in Figure 6. Investigations of the influence of the physicochemical composition showed that BOD, COD-Mn, and Fe were one of the key factors influencing water quality. The high share in the use structure of arable land and building development clearly translated into a change in water chemistry, resulting mainly in an increase in the concentration of nitrates, ammonium ions, phosphates, and sulphates, and in the cations of sodium, potassium, calcium, and magnesium [45]. To sum up, the most general conclusion is that the use of the catchment area of small water bodies has a significant impact, however, only in relation to magnesium and potassium cations [53]. The obtained results of these studies allow us to conclude that the use of the catchment area should be connected with the study of the quality of water running off in built-up rural areas. In the case of the assessment of seasonal differences, significant differences in the magnesium and calcium concentration fluctuations translate into a change in water chemistry, which is illustrated by the large separation of the reservoir waters area [54].

Measures to prevent the degradation of the catchment area should be discussed in scientific works, with a clear recognition of the regularities aimed at assessing the significant impact of human use and activity on the quality of their waters $[55,56]$. The dependence of the concentration of the selected indices of the water quality of small water reservoirs on the use of their catchment areas is also confirmed by the indirectly recorded similar dependence of the nutrient concentrations [57]. In summer, there may be less calcium supply in the coastal zone, especially in the period of low water levels [54]. Our research has shown that water erosion is related to land use, as the results for the EC and TDS corresponded positively in the sections of the stream flowing through the meadow, as well as through the arable land (Figure 6).

In a catchment with a predominance in the structure of agricultural land use, the distribution of the nutrient concentrations results from similar morphometric parameters and catchment uses [58,59]. Therefore, it is considered that water quality indices should be used to measure the concentration in an agricultural catchment with a high fluctuation frequency $[60,61]$. The poor regularity may be related to the rebuilding of the stocks of nitrogen salts dissolved in water, limiting the outflow of the soil components [3]. The accuracy of approximation of the functions of the two variables in the regression modelling depends on the following factors: density of measurement points, division of observation area, and degree of base splined functions. The observed changes may result from factors other than the anthropogenic ones. Regression models are suitable for assessing the quality of the surface water of the catchments used for agricultural use and exposed to water erosion [62]. The MARS model, on the other hand, may also be useful for mountain catchments threatened by surface runoff, where the prediction of variables is difficult to estimate [63]. Therefore, it is advisable to conduct research on water quality in an interdisciplinary manner, combining soil science, hydrogeology, ecohydrology, and water erosion-related elements. However, the MARS method is sensitive to the correlation of independent variables, and to the distribution of data deviating from the normal distribution. This method showed a combined scientific approach using an interrelated prediction model related to the water status. Therefore, the MARS model aids in developing water purification methods in the catchment area. Subsequent studies must include not only the assessment of the impact of soil use on the quality of groundwater and surface water, but should also take into account the appropriate selection of the examined water quality indices, adjusted to the physiographic specificity of the area, its use and management, and the possible impact of the introduced biogeochemical barriers in the catchment. 


\section{Conclusions}

The pollution of water reservoirs in rural and urban areas is proof of the threat to surface waters posed by area and point sources. In the assessment of the chemical state of the flysch stream, rural areas are often classified as heavily polluted. The obtained results indicate the influence of an anthropogenic factor on water quality. When assessing water quality, the EC and TDS parameters turned out to be the determining factor, according to the multidimensional analysis. Our studies confirmed that the physicochemical composition of the flysch stream waters is modified by the anthropogenic factor, especially in the case of water bodies located on slopes with a higher gradient. In some cases, the average values of the water quality indices did not show dependence on the anthropogenic factors. In assessing the impact of the anthropogenic factors, other aspects, such as the proximity of households to watercourses, should also be taken into account, which in the case of disorderly water and sewage management, may have a significant negative impact on water quality. The assessment of water pollution by the Burchard and Dubaniewicz method showed that the tested waters were heavily contaminated, mainly with suspended solids, saline ions, and organic substances, which were influenced by a significant share of arable land, moderate forest cover in the catchment, and a significant risk of water erosion. Because of the low concentrations of nutrients, the waters flowing out of the catchment were not at risk of eutrophication during the study period. For the same reasons, it is predicted that a small retention reservoir may be of a mesotrophic type. In addition, the MARS model has shown that EC and TDS can also have an impact on water quality-the HQ index increased with their values. In order to maintain good water conditions, it will be necessary to monitor water quality in order to be able to react in the event of adverse changes within their catchment areas. Our multiannual results show that no significant changes in the amount of dissolved nitrogen were detected in the examined watercourses, because only its form changed. The obtained results indicate that the use of the catchment area should be treated as a factor modifying the concentration of the tested water quality parameters. Such a disturbance should not be referred to as strong dependencies, but rather it is possible to indicate only certain, usually weak tendencies. The results of the water quality studies showed that in the flysch catchment, measures should be taken to reduce soil erosion, and the inflow of point and area pollution from settlement areas and agriculturally used areas.

Author Contributions: Conceptualization, A.B., T.K. and W.H.; Methodology, A.B., T.K. and W.H.; Data curation, A.B. and T.K.; Formal analysis, A.B., T.K. and W.H.; Visualization, A.B., T.K. and W.H.; Writing-original draft preparation, A.B., T.K. and W.H.; Writing-review and editing, A.B., T.K. and W.H.

Funding: This research received no external funding.

Conflicts of Interest: The authors declare that there is no conflict of interest.

\section{References}

1. Tena, T.M.; Mwaanga, P.; Nguvulu, A. Impact of Land Use/Land Cover Change on Hydrological Components in Chongwe River Catchment. Sustainability 2019, 11, 6415. [CrossRef]

2. Bogdał, A.; Kowalik, T. Variability of values of physicochemical water quality indices along the length of the Iwoniczanka stream. J. Ecol. Eng. 2015, 16, 168-175. [CrossRef]

3. Assouline, S.; Russo, D.; Silber, A.; Or, D. Balancing water scarcity and quality for sustainable irrigated agriculture. Water Resour. Res. 2015, 51, 3419-3436. [CrossRef]

4. Bogdał, A.; Kowalik, T.; Ostrowski, K.; Skowron, P. Seasonal variability of physicochemical parameters of water quality on length of Uszwica river. J. Ecol. Eng. 2016, 17, 161-170. [CrossRef]

5. Zhao, X.; Li, S.; Pu, J.; Miao, P.; Wang, Q.; Tan, K. Optimization of the National Land Space Based on the Coordination of Urban-Agricultural-Ecological Functions in the Karst Areas of Southwest China. Sustainability 2019, 11, 6752. [CrossRef]

6. Bogdał, A.; Ostrowski, K. Loads of selected chemical components delivered by precipitation and flowing away from Włosień stream catchment. Acta Sci. Pol. Form. Circ. 2006, 5, 47-57.

7. Bugajski, P.; Chmielowski, K.; Kaczor, G. Optimization of the percentage of sewage from septic tanks for stable operation of a wastewater treatment plant. Pol. J. Environ. Stud. 2016, 25, 1421-1425. [CrossRef] 
8. Bogdał, A.; Ostrowski, K. Loads of selected components supplied with precipitation and flowing away from the area of two small catchments with diversified use. Acta Sci. Pol. Form. Circ. 2009, 8, 35-45.

9. Liberacki, D.; Szafrański, C. Contents of biogenic components in surface waters of small catchments in the Zielonka Forest. Ann. Set Environ. Prot. 2008, 10, 181-192.

10. Balakrishnan, A.; Ramu, A. Evaluation of heavy metal pollution index (HPI) of ground water in and around the coastal area of Gulf of Mannar biosphere and Palk Strait. J. Adv. Chem. Sci. 2016, 2, 331-333.

11. Bhutiani, R.; Khanna, D.R.; Kulkarni, D.B.; Ruhela, M. Assessment of Ganga river ecosystem at Haridwar, Uttarakhand, India with reference to water quality indices. Appl. Water Sci. 2014, 6, 107-113. [CrossRef]

12. Koc, J.; Skonieczyk, P. Role of Retention Reservoir in Protecting a Lake from Biogenic Substances Running off from Rural Areas. Pol. J. Environ. Stud. 2007, 16, 292-296.

13. Policht-Latawiec, A.; Kapica, A. Influence of Hard Coal Mine on Water Quality in the Vistula River. Ann. Set Environ. Prot. 2013, 15, 2640-2651.

14. Kondracki, J. Geografia Regionalna Polski; Naukowe PWN: Warsaw, Poland, 2009. (In Polish)

15. Soil Survey Staff. Soil Taxonomy: A Basic System of Soil Classification for Making and Interpreting Soil Surveys, 2nd ed.; U.S. Department of Agriculture Handbook 436; Natural Resources Conservation Service: Washington, DC, USA, 1999.

16. Burchard, J.; Dubaniewicz, H. Współczynnik zanieczyszczenia jako miara kompleksowej oceny stopnia zanieczyszczenia wód powierzchniowych na przykładzie Pilicy i Bzury. In Proceedings of the Materiały IX Ogólnopolskiej Konferencji Hydrograficznej, Łódź, Poland, 28-29 September 1981.

17. Łomotowski, J.; Szpindor, A. Nowoczesne Systemy Oczyszczania Ścieków (Modern Wastewater Treatment Systems); Arkady: Warsaw, Poland, 1999.

18. Rozporzadzenie Ministra Środowiska z Dnia 21 Lipca 2016 Roku w Sprawie Sposobu Klasyfikacji Stanu Jednolitych Części wód Powierzchniowych Oraz śRodowiskowych Norm JakośCi dla Substancji Priorytetowych Dz. U. z 2016, poz. 1187; ISAP: Warsaw, Poland, 2016.

19. Wu, J.Y.; Yan, Z.G.; Liu, Z.T.; Liu, J.D.; Liang, F.; Wang, X.N.; Wang, W.L. Development of water quality criteria for phenanthrene and comparison of the sensitivity between native and non-native species. Environ. Pollut. 2015, 196, 141-146. [CrossRef] [PubMed]

20. Mohan, S.V.; Nithila, P.; Reddy, S.J. Estimation of heavy metal in drinking water and development of heavy metal pollution index. J. Environ. Sci. Health 1996, 31, 283-289. [CrossRef]

21. Nasrabadi, T. An index approach to metallic pollution in river waters. Int. J. Environ. Res. 2015, 9, $385-394$.

22. Friedman, J. Multivariate Adaptive Regression Splines. Ann. Stat. 1991, 19, 1-67. [CrossRef]

23. Hastie, T.; Tibshirani, R.; Friedman, J. Elements of Statistical Learning: Data Mining, Inference and Prediction; Springer: New York, NY, USA, 2001.

24. Józefaciuk, C.; Józefaciuk, A. Komentarz do Instrukcji w Sprawie Inwentaryzacji Gruntów Zagrożonych Erozją; Wyd. IUNG: Puławy, Poland, 1999.

25. Fu, J.; Zhao, C.; Luo, Y.; Liu, C.; Kyzas, G.Z.; Luo, Y.; Zhao, D.; An, S.; Zhu, H. Heavy metals in surface sediments of the Jialu River, China: Their relations to environmental factors. J. Hazard. Mater. 2014, 270, 102-109. [CrossRef]

26. Rajda, W.; Kanownik, W. Some water quality indices in small watercourses in urbanized areas. Arch. Environ. Prot. 2007, 33, 31-38.

27. Rajda, W.; Natkaniec, J. The impact of select forms of antropopression on quality of surface waters. Ann. Wars. Agric. Univ.-SGGW Land Reclam. 2001, 31, 65-74.

28. Halecki, W.; Kruk, E.; Ryczek, M. Evaluation of water erosion at a mountain catchment in Poland using the G2 model. Catena 2018, 164, 116-124. [CrossRef]

29. Halecki, W.; Kruk, E.; Ryczek, M. Estimations of nitrate nitrogen, total phosphorus flux and suspended sediment concentration (SSC) as indicators of surface-erosion processes using an ANN (Artificial Neural Network) based on geomorphological parameters in mountainous catchments. Ecol. Indic. 2018, 91, 461-469. [CrossRef]

30. Halecki, W.; Kruk, E.; Ryczek, M. Loss of topsoil and soil erosion by water in agricultural areas: A multi-criteria approach for various land use scenarios in the Western Carpathians using a SWAT model. Land Use Policy 2018, 73, 363-372. [CrossRef]

31. Ostrowski, K.; Bogdał, A. Loads of selected chemical components delivered by precipitation and flowing away from Wronowiec micro catchment. Acta Sci. Pol. Form. Circ. 2006, 5, 37-46. 
32. Bugajski, P.; Chmielowski, K.; Kaczor, G. Reliability of a collective wastewater treatment plant. J. Ecol. Eng. 2016, 17, 143-147. [CrossRef]

33. Skorbiłowicz, M. Identification and evaluation of pollution sources influence on quality of River Orlanka, NE Poland. Pol. J. Environ. Stud. 2007, 16, 304-310.

34. Pytka, A.; Jóźwiakowski, K.; Marzec, M.; Gizińska, M.; Sosnowska, B. Impact assessment of anthropogenic pollution on water quality of Bochotniczanka river. Inf. Ecol. Rural Areas 2013, 3, 15-29.

35. Thapa, R.; Gupta, S.; Reddy, D.V. Application of geospatial modelling technique in delineation of fluoride contamination zones within Dwarka Basin, Birbhum, India. Geosci. Front. 2017, 8, 1105-1114. [CrossRef]

36. Rai, P.K.; Mishra, A.; Tripathi, B.D. Heavy metal and microbial pollution of River Ganga: A case study of water quality at Varanasi. Aquat. Ecosyst. Health Manag. 2010, 13, 352-361. [CrossRef]

37. Thapa, R.; Gupta, S.; Guin, S.; Kaur, H. Assessment of groundwater potential zones using multi-influencing factor (MIF) and GIS: A case study from Birbhum district, West Bengal. Appl. Water Sci. 2017, 7, 4117-4131. [CrossRef]

38. Thapa, R.; Gupta, S.; Gupta, A.; Reddy, D.V.; Kaur, H. Use of geospatial technology for delineating groundwater potential zones with an emphasis on water-table analysis in Dwarka River basin, Birbhum, India. Hydrogeol. J. 2018, 26, 899-922. [CrossRef]

39. European Parliament and European Council. Directive 2000/60/EC of the European Parliament and of the Council Establishing a Framework for Community Action in the Field of Water Policy; OJ L 327, 21.12.2000; European Parliament and European Council: Brussels, Belgium, 2000.

40. Halecki, W.; Młyński, D.; Ryczek, M.; Kruk, E.; Radecki-Pawlik, A. Applying an Artificial Neural Network (ANN) to Assess Soil Salinity and Temperature Variability in Agricultural Areas of a Mountain Catchment. Pol. J. Environ. Stud. 2017, 6, 2545-2554. [CrossRef]

41. Su, S.; Zhi, J.; Lou, L.; Huang, F.; Chen, X.; Wu, J. Spatio-temporal patterns and source apportionment of pollution in Giantang River (China) using neural-based modeling and multivariate statistical techniques. Phys. Chem. Earth Parts A/B/C 2011, 36, 379-386. [CrossRef]

42. Tu, J.; Xia, Z.G. Examining spatially varying relationships between land use and water quality using geographically weighted regression I: Model design and evaluation. Sci. Total Environ. 2008, 407, 358-378. [CrossRef]

43. Hus, T.; Pulikowski, K. Content of nitrogen compounds in water flowing out of small agricultural catchments. Pol. J. Environ. Stud. 2011, 20, 895-902.

44. Koc, J.; Glińska-Lewczuk, K. Hydrochemical characteristics of spring water in young glacial area on the example of the Łyna River headwater. J. Elementol. 2004, 9, 25-34.

45. Purandara, B.K.; Varadarajan, N.; Venkatesh, B.; Choubey, V.K. Surface water quality evaluation and modeling of Ghataprabha River, Karnataka, India. Environ. Monit. Assess. 2012, 184, 1371-1378. [CrossRef]

46. Kowalik, T.; Bogdał, A.; Kanownik, W.; Ostrowski, K.; Rajda, W. Quality and Functional Values of Waters Flowing away from Catchments of Planned Small Retention Storage Reservoirs in the Beskid Makowski and Żywiecki Mts; Monograph of UR Kraków; Wydawnictwo Uniwersytetu Rolniczego w Krakowie: Kraków, Poland, 2010; p. 94.

47. Niczyporuk, A.; Wiater, J. The Influence of Basin use of Chwiszcza and Perebel River on Seasonal Quality of Discharge Water. Pol. J. Environ. Stud. 2006, 15, 397-400.

48. Sharma, S.; Tali, I.; Pir, Z.; Siddique, A.; Mudgal, L.K. Evaluation of physicochemical parameters of Narmada River, MP, India. Researcher 2012, 4, 13-19.

49. Haritash, A.K.; Gaur, S.; Garg, S. Assessment of water quality and suitability analysis of River Ganga in Rishikesh, India. Appl. Water Sci. 2016, 6, 383-392. [CrossRef]

50. Halecki, W.; Barabasz, W. Seasonal potential transmission of pathogens associated with ground drinking water. Pol. J. Environ. Stud. 2017, 26, 2539-2543. [CrossRef]

51. Kumar, M.; Rahman, M.M.; Ramanathan, A.L.; Naidu, R. Arsenic and other elements in drinking water and dietary components from the middle Gangetic plain of Bihar, India: Health risk index. Sci. Total Environ. 2016, 539, 125-134. [CrossRef] [PubMed]

52. Yadav, K.K.; Gupta, N.; Kumar, V.; Sharma, S.; Arya, S. Water quality assessment of Pahuj River using water quality index at Unnao Balaji, M.P.; India. Int. J. Sci. Basic Appl. Res. 2015, 19, 241-250.

53. Smith, C.J.; Oster, J.D.; Sposito, G. Potassium and magnesium in irrigation water quality assessment. Agric. Water Manag. 2015, 157, 59-64. [CrossRef] 
54. Jeziorski, A.; Paterson, A.M.; Watson, I.; Cumming, B.F.; Smal, J.P. The influence of calcium decline and climate change on the Cladocerans within low calcium, circumneutral lakes of 692 the Experimental Lakes Area. Hydrobiologia 2014, 722, 129-142. [CrossRef]

55. Sobhanardakani, S.; Yari, A.R.; Taghavi, L.; Tayebi, L. Application of water quality pollution indices to assess the heavy metal contamination, Case study: Groundwater resources of Asadabad Plain in 2012. Arch. Hyg. Sci. 2016, 5, 221-228.

56. Kanownik, W.; Kowalik, T. Variability of water resources flowing away from small agricultural catchment. Pol. J. Environ. Stud. 2010, 19, 65-71.

57. Kanownik, W.; Pijanowski, Z. A Load of Selected Chemical Components Carried Away by the Outflow from Mountain Catchments. Pol. J. Environ. Stud. 2007, 16, 297-303.

58. Trivedi, R.C. Water quality of Ganga River-An overview. Aquat. Ecosyst. Health Manag. 2010, 13, 347-351. [CrossRef]

59. Naubi, I.; Zardari, N.H.; Shirazi, S.M.; Ibrahim, N.F.; Baloo, L. Effectiveness of water quality index for monitoring Malaysian River Water Quality. Pol. J. Environ. Stud. 2016, 25, 231-239. [CrossRef]

60. Kanownik, W.; Kowalik, T.; Bogdał, A.; Ostrowski, K. Quality categories of stream waters included in the small retention programme in the Malopolska province. Pol. J. Environ. Stud. 2013, 22, 159-165.

61. Yan, C.A.; Zhang, W.; Zhang, Z.; Liu, Y.; Deng, C.; Nie, N. Assessment of water quality and identification of polluted risky regions based on field observations \& GIS in the Honghe river watershed, China. PLoS ONE 2015, 10, e0119130.

62. Halecki, W.; Stachura, T.; Fudała, W.; Rusnak, M. Evaluating the applicability of MESS (matrix exponential spatial specification) model to assess water quality using GIS technique in agricultural mountain catchment (Western Carpathian). Environ. Monit. Assess. 2019, 191, 26. [CrossRef] [PubMed]

63. Sharda, V.N.; Prasher, S.O.; Patel, R.M.; Ojasvi, P.R.; Prakash, C. Performance of Multivariate Adaptive Regression Splines (MARS) in predicting runoff in mid-Himalayan micro-watersheds with limited data. Hydrol. Sci. J. 2008, 53, 1165-1175. [CrossRef]

(C) 2019 by the authors. Licensee MDPI, Basel, Switzerland. This article is an open access article distributed under the terms and conditions of the Creative Commons Attribution (CC BY) license (http://creativecommons.org/licenses/by/4.0/). 